\title{
Por um direito internacional de proteção dos consumidores: sugestões para a nova lei de introdução ao Código Civil brasileiro no que se refere à lei aplicável a alguns contratos e acidentes de consumo*
}

\section{Claudia Lima Marques**}

\section{INTRODUÇÃO}

Este artigo é uma homenagem a José Francisco Rezek, "credor do incondicional reconhecimento de todos aqueles estudiosos do Direito Interna- cional." O grande jurista e professor brasileiro, Francisco Rezek, que com seus ensinamentos, cortesia e extrema competência, honra nosso país e nossas Universidades, ao prefaciar um livro sobre Proteção do consumidor no

\footnotetext{
* A autora agradece ao dr. Jean Michel-Arrighi, renomado consumerista e diretor jurídico da OEA, Washington, pelo honroso convite para ministrar o curso na OEA em 2000, origem destas observações sobre a CIDIP e ao dr. Ricardo Morishita, diretor do CPDC/MJ, pelo convite para colaborar com o CT7 do Mercosul e em sugestões à LICC. Artigo já publicado no livro em homenagem à Francisco Rezek Direito Internacional, org. Wagner Menezes, Ed. UNIJUÍ, Ijuí, 2004, Anais do $2^{\circ}$ Congresso de Direito Internacional, 25-28 de agosto de 2004, org. PUC/PR, Curitiba.

** Professora titular de Direito Internacional Privado da Universidade Federal do Rio Grande do Sul, doutora em Direito pela Universidade de Heidelberg, Alemanha; mestre em Direito Civil e Direito Internacional Privado pela Universidade de Tübingen e Especialista em Integração Européia pelo Europa-Institut, Saarbrücken, Alemanha; ex-presidente do Instituto Brasileiro de Política e Direito do Consumidor; vice-presidente da Association Internationale de Droit de la Consommation, Bruxelas.

1 Permito-me aqui usar o elogio que o próprio homenageado utilizou para honrar os estudos de Pontes de Miranda, "credor do incondicional reconhecimento dos estudiosos do tema", REZEK, José Francisco. A nacionalidade à luz da obra de Pontes de Miranda. Revista Forense, Rio de Janeiro, v. 74, n. 263, jul./set. 1978, p. 15.
} 
Mercosul e na União Européia, destacou as diferenças que a efetividade do Direito, em cada uma das sociedades nacionais, exige. ${ }^{2}$ Segundo o mestre, a simples importação de normas de países principais do Direito Comparado, ${ }^{3}$ não é suficiente: o exame deve ser profundo, de convergências e de divergências, para alcançar-se a efetividade da norma proposta ou aceita. Assim é com o delicado tema da necessidade de proteção especial dos consumidores, em suas relações (contratuais ou extracontratuais) internacionais.

Igualdade é o tratamento igual dos iguais e diferente daqueles que - por circunstâncias externas, especialidade profissional ou falta de informação e situação econômica e fática - diferentes são. ${ }^{4}$ Como ensina o nosso homenageado, também este ramo do Direito, tradicionalmente, conhece normas especiais para que os agentes privados atinjam esta esperada igualdade. ${ }^{5}$

Relembra ainda o mestre Rezek, que as relações internacionais devem seguir as linhas estabelecidas e o espírito delineado pela Constituição. ${ }^{6}$ Efetivamente, há que se considerar que a Constituição democrática de 1988 incluiu dois mandamentos ou Gebote imperativos de distinção e de proteção dos interesses dos consumidores por normas especiais: no art. 48 dos Atos e Disposições Transitórias mandou elaborar um Código de Defesa do Consumidor, com normas especiais a atravessar todos os ramos do direito

2 REZEK, José Francisco. Prefácio. In: Fellous, Beyla Esther, Proteção do consumidor no Mercosul e na União Européia, São Paulo: Revista dos Tribunais, 2004, p. 11-12.

3 REZEK, José Francisco, Le droit international de la nationalité. Recueil des Cours, v. 198, 1986-1987, p. 341.

4 A igualdade é uma das grandes meta-narrativas da modernidade (Brilmayer, Lea. Postmodernism in American Choice of Law. In: LIBER Memorialis François Laurent. Bruxel, 1989, p. 702 e 705), mas a pós-modernidade tende a destacar o que há de "diferente" e "privilegiador" nestes novos direitos humanos (veja os ensinamentos de Erik Jayme (JAYME, Erik. Identité culturelle et intégration: Le droit internationale privé postmoderne. Recueil des Cours, Haye, n. 2, 1995, p. 33 et seq.), permitindo a desigualdade formal para atingir a igualdade material. No caso, as normas nacionais sobre proteção do consumidor, como o CDC ou Lei 8.078/90, asseguram-se direitos ao consumidor para alcançar a igualdade material dos desiguais, garantem-se direitos de escolha, reflexão, informação e transparência para proteger sua abalada liberdade ou autonomia de vontade dos consumidores nos contratos (art. 4,6, 18 a 54 do CDC) e o direito de prevenção de danos e de indenização integral em caso de acidentes de consumo (art. 8 a 17 do CDC).

5 Veja neste sentido o belo artigo do homenageado, Rezek, José Francisco, Aspectos elementares do Estatuto da Igualdade, in Boletim do Ministério da Justiça, Lisboa, n. 277, p. 5-12, jun. 1978.

6 REZEK, José Francisco. As relaç̃es internacionais na Constituição da primeira República. Revista Arquivos do Ministério da.Justiça, v; 30, n. 126, jun. 1973, p. 107 et seq. 
que importassem para a proteção deste sujeito vulnerável (direito civil, direito penal, direito administrativo, direito processual civil e penal e, porque não, direito internacional privado!), assim como, o art. $5^{\circ}$, inciso XXXI esclareceu que a proteção deste sujeito econômico alcança nível de direito fundamental (liberdade e garantia fundamental $)^{7}$ no ordenamento jurídico brasileiro: O Estado promoverá, na forma da lei, a defesa do consumidor.

Assim, se relações privadas de consumo assumem hoje também um crescente caráter internacional, devem preocupar os jus-privatistas internacionais. Em outras palavras, num mundo de crescentes áreas de complexidade, rapidez e globalização, ${ }^{8}$ há um crescimento na importância do Direito Internacional Privado ou dos conflitos de leis no espaço também em relação aos consumidores, atores leigos deste mercado internacional, ${ }^{9}$ cuja porta de entrada pode ser o simples computador $^{10}$ (televisão, fax, a tela do palmtop ou mesmo do telefone celular), ${ }^{1} \mid$ pode ser a evolução da globalização, ${ }^{12}$ o

$7 \mathrm{Na}$ expressão de Alexy, estes direitos asseguram/garantem/estimulam a efetivação da Dignidade do Homem, sua Liberdade e Igualdade ("...was die Verwirklichung von Menschenwürde, Freiheit und Gleichheit fordert"), ALEXY, Robert. Theorie der Grundrechte, Suhrkamp. Frankfurt, 1996, p.15.

8 Aceitarei aqui a definição de globalização feita por CASTELLS, Manuel. End of millennium: the information age: Economy, Society and culture,. Oxford: Blackwell, 1998, v. 3, p. 1: " $[\ldots]$ this is indeed a time of change a technological revolution, centered around information, has transformed the way we think, we produce, we consume, we trade, we manage, we communicate, we live, we die, we make war, and we make love. A dynamic global economy has been constituted around the planet, linking up valuable people and activities from all over world, while switching off from the networks of power and wealth, people and territories dubbed as irrelevant from the perspective of dominant interests..."

9 Veja Marques, Cláudia. A insuficiente proteção do consumidor nas normas de direito internacional privado: da necessidade de uma Convenção Interamericana (CIDIP) sobre a lei aplicável a alguns contratos e relações de consumo. Revista dos Tribunais, São Paulo, v. 90 , n. 788 , p. 11-56, jun. 2001, que utilizarei como base para muitas observações aqui repetidas.

10 Sobre o tema veja a interessante análise do jus-filósofo argentino Ciúro Caldani, Miguel Angel. La debilidad del consumidor en la sociedad de consumo. Investigación y Docencia, Rosario, n. 28, 1997, p. 33 et seq.

11 Veja também a juíza brasileira Fernanda Moron (A internet e o direito. Revista Consulex, mar. 1997, p. 64): "Como se vê, na medida que as relações que surgem pela Internet transcendem fronteiras, maior necessidade teremos de recorrer a regras do Direito Internacional, ramo jurídico que com certeza apresentará sensível crescimento.."

12 Sobre os problemas e a trivialização da expressão "globalização", veja a análise lúcida de Porto, Ronaldo. Globalização e Direito do Consumidor. Revista de Direito do Consumidor, São Paulo, n. 32, [s.d.], p. 45. 
crescente turismo, as áreas de livre comércio e processos de integração, ${ }^{13}$ como o Mercosul ${ }^{14}$ ou a futura ALCA (Parte I) ${ }^{15}$

Sem dúvida, como ensina Francisco Rezek, ${ }^{16}$ é pela mão do Direito Internacional Público que o Direito Internacional Privado pode conseguir a maior efetividade, propondo, por exemplo, um tratado de proteção dos consumidores. Tendo tido a honra de ministrar aulas no Curso de Direito Internacional da OEA-Organização dos Estados Americanos, em agosto de 2000, sobre "A proteção do consumidor: aspectos de direito privado regional e geral", ${ }^{17}$ onde concluí pela necessidade e oportunidade de elaborarmos na região uma Convenção Interamericana de Direito Internacional Privado (CIDIP) para a proteção do consumidor turista e do consumidor que contrata à distância, em especial no crescente comércio eletrônico, considero que esta lição do mestre foi honrada. ${ }^{18}$ Agora, gostaria de trazer os resultados deste curso para o âmbito interno do direito brasileiro, pois afinal as convenções têm uma dinâmica própria e aplicam-se apenas a alguns Estados, e se desejamos uma proteção ampla e efetiva dos consumidores devemos propor também a inclusão de normas específicas de proteção deste sujeito de direitos fundamentais também em nossa futura Lei de Introdução ao Código Civil (Parte II).

Note-se, ainda que a importância e atualidade do tema estão dadas no Brasil pela falta de sugestões específicas de defesa do consumidor nos projetos em trâmite hoje para acompanhar a entrada em vigor do novo Código Civil (Lei

13 Veja sobre o tema, Perin Júnior, Ecio. A globalização e o direito do consumidor. Barueri: Manole, 2003, p. 45 et seq.

14 Sobre o tema, duas obras específicas, Fellous, Beyla Esther. Proteção do consumidor no Mercosul e na União Européia. São Paulo: Revista dos Tribunais, 2004 e Batisti, Leonir. Direito do consumidor para o Mercosul. Curitiba: Juruá, 1998.

15 Comentando o tema sob a ótica brasileira, veja Marques, Claudia Lima. A proteção do consumidor de produtos e serviços estrangeiros no Brasil: primeiras observações sobre os contratos à distância no comércio eletrônico. Revista de Direito do Consumidor, São Paulo, v. 41, p. 39-80, jan./mar. 2002, Some recent developments in Private International Law in Brazil. Japanese Yearbook of Private International Law, Tóquio, v. 4, 13-50, 2002. 16 Veja a importância dos tratados na evolução do Direito, in Rezek, José Francisco. Direito internacional público: curso elementar. 9. ed. São Paulo: Saraiva, 2002, p.11 et seq.

17 A íntegra do Curso foi publicada pela OEA, em Washington, veja Marques, Claúdia Lima. A proteção do consumidor: aspectos de direito privado regional e geral. In: Curso de Derecho Internacional-OEA/CIJ. Washington: OEA, 2001, p. 657-780.

18 Rezek, Francisco. A insuficiente proteção do consumidor nas normas de Direito Internacional Privado - Da necessidade de uma Convenção Interamericana (CIDIP) sobre a lei aplicável a alguns contratos e relações de consumo. Revista dos Tribunais, São Paulo, v. 90, n. 788, p. 11-56, jun. 2001. 
10.406/2003). ${ }^{19}$ Neste sentido, concluise facilmente que as normas de Direito Internacional Privado no país estão defasadas e mister refletir em como nós, consumeristas e jus-privatistas, aceitando o desafio do homenageado, podemos ajudar a elevar a efetividade de nossas normas para a proteção dos mais fracos. Vejamos.

\section{A INSUFICIÊNCIA DAS REGRAS DE DIREITO INTERNACIONAL PRIVADO BRASILEIRO E O FENÔMENO DO CONSUMO INTERNACIONAL}

Efetivamente, se, algum tempo atrás, a proteção do consumidor era um tema de direito interno, eis que a atuação da maioria das pessoas restringia-se ao território do seu país, uma relação típica nacional, sem qualquer elemento de internacionalidade,$^{20}$ hoje a realidade regional e nacional é diversa. Com a abertura dos mercados a produtos e serviços estrangeiros, com a crescente integração econômica, a regionalização do comércio, as facilidades de transporte, o turismo em massa, o crescimento das telecomunicações, da conexão em rede de computadores, do comércio eletrônico, não há como negar que o consumo já extrapola as fronteiras nacionais. ${ }^{21}$ Os bens estrangeiros estão nos supermercados, os serviços são oferecidos por fornecedores com sede no exterior no telemarketing, através da televisão, do rádio, da internet, da publicidade massificada no dia-a-dia da maioria dos cidadãos de nossas metrópoles. ${ }^{22}$ Não é mais necessário

19 Veja PL 243/2002, PL 87/97, PL 4.905/95, PL 4.782/90, PL 377/89 sobre as modificações na LICC. Outro bom exemplo é que dos 80 PLs apensados ao Projeto de Lei 1825/91 de atualização do CDC, apenas três (PL 884/95, PL 2646/96 e PL 2893/97) tratam de temas de consumo internacional e isto no que se refere à informação prestada ao consumidor, tema já tratado pelo art. 31 do CDC.

20 Assim ensina Hoffman, Bernd Von. Über den Schutz des Schächeren bei internationalen Schuldvertragen, RabelsZ, n. 38, 1974, p. 401, explicando que nos casos excepcionais se podia usar a cláusula de ordem pública para proteger este "mais fraco" em seus contratos/ acidente/turismo internacional.

21 Assim também observam os mestres uruguaios Hargain, Daniel; Mihali, Gabriel. Circulación de bienes en el Mercosur. Montevidéu: Júlio César Faira, 1998, p. 504.

22 Assim concordam Benjamin, Antônio Herman de V. Consumer protection in lessdeveloped countries: the latin american experience. In CONSUMER law in the global economy. Asgate: Brookfield, USA, 1996, p. 50 e Reich, Norbert. Consumerism and citizenship in the Information Society-The case of eletronic contracting, In: Consumer law in the information society. Haia: Kluwer, 2001, p. 163 et seq. Veja Marques, Claudia Lima (Org.). Estudos sobre a proteção no Brasil e no Mercosul. Porto Alegre: Livraria do Advogado, 1994 e Marques, Claudia Lima. El código brasileño de defensa del consumidor y el Mercosur. In MERCOSUR: perspectivas desde el derecho privado. Buenos Aires: Editorial Universidad, 1996, p. 199-226. 
viajar, ser um consumidor-ativo, um consumidor turista, deslocar-se para ser um consumidor, que contrata de forma internacional ou se relaciona com fornecedores de outros países. ${ }^{23}$ As próprias formas de produção e montagem hoje são internacionais, os contatos internacionais de consumo e o turismo massificaram-se. ${ }^{24} \mathrm{O}$ fenômeno do consumidorpassivo internacional e o do consumidor-ativo internacional já chegou ao Brasil. Consumir de forma internacional é típico de nossa época. O serviço ou produto estrangeiro é status, é bem simbólico na atual cultura de consumo; ${ }^{25}$ o turismo, as viagens, o ser consumidorativo de forma internacional faz parte da procura pós-moderna dos prazeres, do lazer individual, da realização dos sonhos e do imaginário, é uma distinção social cada vez mais importante. ${ }^{26}$

Como sempre afirmamos, o direito do consumidor tem uma vocação internacional, ${ }^{27} \mathrm{e}$, em nenhum outro setor do direito privado, os modelos e as inspirações estrangeiras e supranacionais estiveram tão presentes. Em teoria, o consumidor não deve ser prejudicado, seja sob o plano da segurança, da qualidade, da garantia ou do acesso à justiça somente porque adquire produto ou utiliza serviço proveniente de um outro país ou fornecido por empresa com sede no exterior. ${ }^{28}$ Em teoria, o consumidor turista, o viajante, aquele que adquire produtos e serviços em outro país deve poder contar com uma proteção mínima aos seus interesses, assim como aquele que assistindo publicidade de fabricante

23 A distinção entre consumidor-ativo (que se desloca de um país para outro) e consumidorpassivo (que recebe a informação, que contrata em seu país, sem deslocamento físico) é muito utilizada na Alemanha e será aqui seguida para facilitar a exposição. Veja, por todos, usando a expressão JAYME, Erik; Kohler, Christian, Europäisches kollisionsrecht 1999Die Abendstunde der Staatsverträge. IPRAX, 1999, p. 404.

24 Assim Benjamin, Antonio Herman de V. O transporte aéreo e o Código de Defesa do consumidor. Revista AJURIS, Porto Alegre, março 1998, v. 2 edição especial, p. 499 et seq. Veja também MARQUES, Cláudia Lima. A responsabilidade do transportador aéreo pelo fato do serviço e o Código de Defesa do Consumidor - Antinomia entre norma do CDC e de leis especiais. Revista Direito do Consumidor, São Paulo, v. 3 p. 155-197, 1992.

25 Aqui estamos seguindo os ensinamentos de Featherstone, Mike. Cultura de consumo e pós-modernismo, São Paulo: Studio Nobel, 1995, p. 31.

26 Assim Ibidem, p. 31.

27Veja Bourgoignie, Thierry. Eléments pour une théorie du droit de la consommation, CDC-Story Sciencia, Bruxelas, 1988, p. 215 et seq.

28 Marques, Cláudia Lima. Regulamento comum de defesa do consumidor do Mercosul: primeiras observações sobre o Mercosul como legislador da proteção do consumidor. Revista Direito do Consumidor, São Paulo, v. 23-24, [s.d.], p. 79 e também, no mesmo sentido no Mercosul, Stiglitz, Gabriel. El derecho del consumidor en Argentina y en el Mercosur. Derecho del Consumidor, v. 6, 1995, p. 20. 
localizado em outro país, resolve contratar à distância. Houve uma substancial mudança na estrutura do mercado, ${ }^{29}$ uma globalização também das relações privadas de consumo, ${ }^{30}$ que põe à luz as falhas do mercado ${ }^{31}$ e os limites da noção fictícia de "soberania" do consumidor no mercado atual. ${ }^{32}$ A sua posição é cada vez mais fraca ou vulnerável e o desequilíbrio das relações de consumo é intrínseco, ${ }^{33}$ necessitando efetiva tutela e positiva intervenção dos Estados e dos organismos internacionais legitimados para tal. ${ }^{34}$

A pergunta é se o nosso ordenamento jurídico está preparado para esta internacionalização das relações de consumo. Há grande especificidade nestas relações jurídicas internacionais, que, se bem representam apenas uma parcela do comércio internacional, têm um potencial econômico e político importantíssimo. A realidade é que, nas
Américas, as leis nacionais de proteção dos consumidores, de direito civil e de direito comercial, e as normas gerais raramente possuem normas de direito internacional privado especiais para a tutela efetiva dos contratantes mais fracos, das vítimas dos acidentes com produtos e serviços defeituosos, dos turistas, dos que recebem a publicidade, o marketing agressivo e emocional de nossos tempos, enfim, dos consumidores domiciliados ou nacionais destes países. A norma nacional de Direito Internacional Privado (aqui denominado DIPr.) geralmente é antiga ${ }^{35}$ a única atualização veio através das conferências interamericanas de Direito Internacional Privado (CIDIPs), organizadas no seio da OEA. As CIDIPs, porém, nenhuma conexão mais favorável impuseram especificamente sobre a proteção do consumidor.

Incontroverso é que a proteção deste agente econômico mais fraco, ${ }^{36}$

29 Cf. Botana García, Gema; Ruiz Muñoz, Miguel (Coord.). Curso sobre protección jurídica de los consumidores. Madrid: Ciencias Juridicas, 1999, p. 8.

30 Veja, por todos, Ghersi, Carlos Alberto. Postmodernidad. [s.n.t.], p. 139 et seq.

31 Assim Bourgoinie, Élements, p. 64 et seq.

32Assim Botana, op. cit., p. 8 e Bourgoinie, Élements, p. 64.

33 Calais-Auloy, Jean, Droit de la consommation. 3.ed.. Paris: Dalloz, 1992, p. 1, considera que este desequilíbrio sempre existiu, apenas agora está qualificado de tal forma que é um dos objetivos sociais de nosso tempo, proteger o consumidor em posição estruturalmente mais fraca.

34 Marques, El código brasileño, p. 199 , também Botana Garcia; Ruiz Muñoz, Curso sobre..., p. 8 menciona a atual "degradación de la posición del consumidor".

35 Exceção feita aos EUA e Venezuela, veja Parra-Aranguren, Gonzalo, Curso general de derecho internacional privado: problemas selectos. Caracas: Fundación Fernando Parra Aranguren, 1991, p.51 et seq.

36 Assim Benjamin, Antônio Herman. El código brasileño de protección del consumidor. In: Politica y derecho del consumo. Bogotá: El Navegante, 1998, p. 480. 
geralmente pessoa física não profissional, que age, contrata ou negocia no mercado de consumo o fornecimento de produtos e serviços sem fins lucrativos e fora de sua atividade profissional principal, interessa hoje ao Direito Internacional Privado, como comprova o Protocolo de Santa Maria de 1998 no Mercosul e ao Direito Internacional Privado geral, como demonstrou o projeto de 1980 da Convenção de $\mathrm{Haia}^{37}$ e a Convenção Européia de Roma de 1980.

Pergunta-se, aqui, se os esforços até agora realizados foram suficientes ou devem ser renovados. As normas nacionais deveriam ser suficientes para proteger o consumidor no novo mercado sem fronteiras, ao mesmo tempo em que não devem ser usadas pelos países como novas barreiras à livre circulação de produtos e de serviços dos países integrados ou que pertencem a uma zona de livre comércio ou união aduaneira, como a NAFTA, a ALCA e o Mercosul. ${ }^{38}$ Note-se, porém, que as normas nacionais, reguladoras do comércio internacional, assim como o direito uniforme do comércio internacional ou a denominada lex mercatoria, geralmente não se preocupam em proteger o consumidor, ${ }^{39}$ ao contrário tentam excluir estes contratos de seu campo de aplicação. ${ }^{40}$

Na Europa, desde a década de 1970, os doutrinadores propugnam a necessidade do Direito Internacional Privado voltar-se para a proteção dos mais fracos, especialmente dos consu-

37 Veja Mehren, Arthur Von. Law applicable to certain consumer sales: texts adopted by the fourteenth session and explanatory report. Haia: Bureau Permanent de la Conférence, 1982, p. 6, que explica como este projeto de convenção visava complementar a Convenção de Haia de 1955 sobre lei aplicável à venda internacional de mercadorias, o que nunca chegou a acontecer, pois o referido projeto, findo em 1980, nunca chegou a ser aprovado, superado que foi pela própria Convenção de Roma da CEE, assinada naquele mesmo ano com seu famoso art. $5^{\circ}$ sobre o mesmo tema.

38 Assim Krämer, Ludwig. La CEE et la protection du consommateur. Bruxelles, 1988, p. 377. Veja também o nosso artigo, Marques, op.cit., p. 199 et seq.

39 Assim Botana Garcia; Ruiz Muñoz, op. cit. p. 21, citando os princípios de UNIDROIT sobre os contratos comerciais internacionais e a Convenção de Viena sobre compra e venda internacional de mercadorias de 1980.

40 O exemplo mais importante são as normas uniformizadoras da Convenção da ONU sobre Compra e Venda de mercadorias de 1980, conhecida como Convenção de Viena de 1980 , que em seu art. $2^{\circ}$ e e art. $5^{\circ}$, procuram evitar a aplicação destas normas do comércio internacional aos contratos com consumidores-leigos. Veja sobre o tema Hargain; Mihali, Circulación..., p. 506 e GARRO, Alejandro Miguel; Zuppi, Alberto Luis. Compraventa internacional de mercaderías. Buenos Aires: La Rocca, 1990, p. 81. 
midores, ${ }^{41}$ incluindo novos elementos de conexão mais flexíveis e adaptados à tutela do vulnerável nestas situações privadas internacionais, face à falência das ditas conexões "neutras" e rígidas, mais adaptáveis ao relacionamento entre iguais ou pelo menos entre profissionais, comerciantes. ${ }^{42}$ Estas normas especiais de DIPr. seriam necessárias até que a harmonização das normas materiais de defesa do consumidor, pelo menos nos temas principais da internacionalização então vivida, acontecesse na Europa ${ }^{43}$

Com as devidas adaptações, parece-me que exatamente este momento histórico está se repetindo no espaço interamericano. O sistema interamericano está claramente aberto para o comércio internacional e a regionalização, mas ainda possui um ordenamento jurídico lacunoso e insuficiente para proteger os agentes econômicos mais fracos de seu mercado, os consumidores. Uma evolução seria necessária.

Neste sentido, unindo-me aos doutrinadores uruguaios e argentinos, ${ }^{44}$ que me precederam nestes estudos sobre a proteção do consumidor em situações internacionais, aproveitei o convite do Comitê Jurídico Interamericano para sugerir a elaboração de uma Convenção Especializada de Direito Internacional Privado sobre proteção do consumidor em duas situações específicas, a do consumidor-turista, especialmente aquele que se utiliza do sistema de multipropriedade ou time-sharing, e a do consumidor que contrata à distância, seja por meios tradicionais ou por novos meios eletrônicos. Inspiro-me na atual doutrina européia, a qual continua indicando que o tema da proteção do consumidor é básico para os mercados globalizados, ${ }^{45}$ é a

41 Ficaram famosos os trabalhos de Zweigert, Neuhaus e Lando, sugerindo o primeiro que o DIPr. incluisse valores sociais e, o segundo, que se abandonasse a autonomia de vontade nos contratos entre contratantes fracos e fortes, como os de consumo e o terceiro, pragmaticamente, que passasse o DIPr. a escolher como conexão o domicílio do contratante mais fraco, veja também o estudo de Hoffmann, Bernd Von. Über den Schutz des Schächeren bei internationalen Schuldvertragen. RabelsZ, n. 38, p. 396-420, 1974., p. 398 et seq. e de Kropholler, Jan. Das kollisionsrechtliche System des Schutzes der schwächeren Vertragspartei. RabelsZ, n. 42, p. 634-661, 1978, p. 634 et seq.

42Assim Ibidem, p. 636.

43Assim manifesta-se, denominando a ordem jurídica alemã da época de "lacunosa e insegura para os contratantes mais fracos", Ibidem, p. 635.

44 Mencione-se aqui especialmente os estudos aqui citados de Boggiano, Dromi e Toniollo, na Argentina, Arrighi e os autores Hirgain/Mihali, no Uruguai.

45Assim a exposição forte e crítica de Junker, Abbo. Von Citoyen zum Consommateur: Entwicklung des internationalen Verbraucherschutzrechts. IPRAX, 1998, p. 67 et seq., afirmando que o consumidor é o "citoyen", o cidadão político europeu do futuro. Junker inspira-se em trabalho semelhante de Westphalen, Von. Vom Citoyen über den Bourgeois zum Consommateur. ZIP, 1995, p. 1643, veja Junker, op. cit., p. 67. 
maneira de harmonizar os interesses do mercado com os anseios de respeito aos novos direitos humanos em tempos pósmodernos, de individualismo crescente e de integração econômica cada vez mais desenvolvida. ${ }^{46}$ Esta sugestão de CIDIP não deve aqui ser repetida, logo, cabe agora estudar quais as sugestões para a LICC brasileira.

\section{A) A especificidade do consumo internacional e a Lei de Introdução ao Código Civil (LICC/1942)}

Repita-se aqui, em parte, nosso estudo para a elaboração da CIDIP. Inicialmente, mister estabelecer claramente quais são as especificidades das relações de consumo internacionais se comparadas às relações comerciais internacionais. Certo é que no comércio internacional também há a barreira da língua, a barreira da falta de informações, as normas e costumes dife- rentes, as dificuldades e a insegurança na entrega e no pagamento, as dificuldades na garantia, no nível qualidade e no serviço pós-venda ${ }^{47}$ mas estas dificuldades qualificam-se quando o parceiro contratual é um leigo, um consumidor. ${ }^{48} \mathrm{~A}$ primeira das especificidades do consumo internacional é, pois, o desequilíbrio intrínseco informativo e de especialização entre os parceiros contratuais internacionais face ao status leigo e vulnerável do parceiro-consumidor. ${ }^{49} \mathrm{O}$ comércio internacional, as relações de compra e venda ou de prestação de serviços entre pessoas com sede em países diferentes, geralmente ocorre entre pessoas jurídicas ou profissionais, comerciantes e empresários, logo, especialistas e profissionais para poderem se movimentar no cenário dos negócios internacionais. No consumo internacional não é esta a realidade. O parceiro-consumidor é atraído ou por métodos agressivos de marketing (por

46 Esta análise pós-moderna é uma homenagem ao mestre orientador de Doutorado, prof. dr. dr.h.c. Erik Jayme, da Universidade de Heidelberg, que em seu brilhante curso de Haia lançou sua teoria dos reflexos da pós-modernidade no direito. Veja Jayme, Identité..., p. 33 et seq.

47 Sobre as dificuldades do comércio internacional veja Feldstein de Cárdenas, Sara. Contratos internacionais. Buenos Aires: Abeledo-Perrot, 1995, p. 60 et seq. e Moura Ramos, Rui Manuel; Soares, Maria Angela Bento. Contratos internacionais. Coimbra: Almedina, 1986, p. 9 et seq. Chega-se a advogar, pela sua especificidade mesmo a existência de um direito do comércio internacional, veja Jadaud, Bernard; Plaisant, Robert. Droit du commerce international. Paris: Dalloz, 1991, p. 1.

48 Assim COMISSÃO EUROPÉIA. Guía del consumidor europeo en el mercado único. Bruxelas: Comisión Europea, 1995, p. 15-16.

49 Veja sobre a vulnerabilidade do consumidor, Marques, Cláudia. Contratos no código de defesa do consumidor. São Paulo: Revista dos Tribunais, 1999, p. 140 et seq. 
exemplo, telemarketing, teleshopping, vendas emocionais de time-sharing para turistas) ou por preços reduzidos (descontos, redução nos tributos, envio gratuito, etc.), pelo senso de aventura (por jogos, apostas, prêmios), ou por sua própria ignorância quanto às dificuldades nas transações transnacionais (parco conhecimento da língua para entender a oferta ou a publicidade, mito da qualidade superior dos produtos importados, produtos-novidade, desconhecidos em países emergentes, pela falta de conselhos jurídicos ou de um departamento jurídico para a negociação, confiança que a marca terá serviços pós-venda em seu país, etc.). As regras do comércio internacional, as regras de direito internacional privado, em geral, estão construídas sobre a base do profissionalismo e especialidade dos parceiros envolvidos, ${ }^{50}$ a proteger quem vende, quem fornece o produto e o serviço, não daquele que apenas paga (comprador, recebedor do serviço, "consumidor").

Outra especificidade do consumo internacional é a sua falta de "continuidade" ou sua "descontinuidade". Os atos de comércio caracterizam-se pela repetição e mesmo os contratos internacionais tendem a abrir mercados e relações bastante cooperativas e duradouras. Os contratos de consumo internacionais, ao contrário, são geralmente de troca, não possuem longa duração, nem se beneficiam do sistema financeiro internacional ou transferem tecnologia no sentido estrito da palavra. ${ }^{51}$ Por exemplo, ser turista é um fenômeno pontual e sazonal, comprar à distância de um fornecedor da Califórnia (EUA) um determinado soft ware ou livro também é um fenômeno eventual e descontínuo. As regras do comércio internacional, as regras de direito internacional privado, em geral, estão construídas sobre a base da confiança e da continuidade, do crescer de relações: aquele que compra internacionalmente, voltará a comprar se a "execução" for adequada, há que se proteger aquele que vende, aquele que envia sem muitas garantias e sem conhecer seu cliente propriedade sua

50 Neste sentido destaque a decisão do STF não considerando "consumo" relações de importação de matéria prima entre dois comerciantes, SENTENÇA ESTRANGEIRA CONTESTADA n ${ }^{\circ}$ 5.847-1, acórdão promulgado em 01.12.1999, Rel. Min. Maurício Corrêa. Veja meus comentários a esta decisão do STF, junto com Turkienicz, Eduardo. Comentários ao acórdão do STF no caso Teka vs. Aiglon : em defesa da teoria finalista de interpretação do art. $2^{\circ}$ do CDC. Revista Direito do Consumidor, São Paulo, v. 36, 2000, p. 221 et seq.

51 Rara exceção seria o contrato de time-sharing ou multipropriedade, que é uma relação duradoura, se bem que fluída, por vezes nacional ou internacional (com círculos de trocas), veja sobre assunto o mestre brasileiro, Tepedino, Gustavo. Multipropriedade imobiliária. São Paulo: Saraiva, 1993 e meu artigo, Marques, Cláudia Lima, Contratos de time-sharing no Brasil e a proteção dos consumidores: crítica ao direito civil em tempos pós-modernos. Revista Direito do Consumidor, São Paulo, v. 22, p. 64-86, 1997. 
para país distante. No consumo internacional, a prioridade se inverte, o comprador não é um comerciante, não é expert, é, ao contrário, leigo, compra pelo preço, pelas qualidades apregoadas, confia em uma, muitas vezes, inexistente proteção legal e assume enormes riscos ao viabilizar o número de seu cartão de crédito.

As outras especificidades são o pequeno valor, a massificação e a difícil re-execução. O consumo internacional é hoje um fenômeno de massas, basta pensar o turismo sazonal, o timesharing, com seus círculos de trocas internacionais, os pacotes turísticos para grandes festas, os transportes aéreos, os cruzeiros marítimos, etc. ${ }^{52}$ Individualmente considerado o contrato internacional de consumo tem, porém, pequeno valor, seja para a economia de um país ou de um fornecedor. Este pequeno valor dificulta em muito o acesso à justiça, faz com que a lide fique reprimida, dificulta que o consumidor assuma gastos exagerados, seja para reclamar, para procurar novamente o fornecedor, para fazer valer sua garantia, etc. O consumo internacional ainda possui uma última especificidade, que lhe é comum com os serviços em geral, sua re-execução, em caso de frustração das expectativas do contra- tante consumidor é bastante dificultosa. Em caso de turismo, reeditar algo, uma excursão, dias de férias em praia poluída, recuperar o conforto de um hotel em país distante e assim por diante, é tarefa quase impossível e a resposta será apenas econômica, com as perdas e danos respectivas. Em matéria de contratos à distância, a eventualidade da perda de tempo, da perda de uma chance e de acontecerem danos morais anexos à má-execução do contrato internacional de consumo também são quase uma constante, o melhor é prevenir os danos e minimizá-los, ou a resposta será apenas econômica, com as perdas e danos respectivos.

Destaque-se, por fim, que há um forte componente político-econômico nas regras de proteção nacional e internacional dos consumidores, pois se um país exportador mantém um alto nível de proteção de seus consumidores aumenta a qualidade de seus produtos, que encontrarão maior aceitação internacional. Se um país turístico, aumenta o grau de proteção dos turistas e facilita o seu acesso à Justiça, garante melhores condições ao turismo e facilita o desenvolvimento deste importante setor econômico. Em outras palavras, regras sobre o direito do consumidor interessam à competitividade do mercado

52 A doutrina européia alerta desde a década de 80 e, especialmente na década de 90 , que o turismo de massa é um dos setores econômicos que mais cresce na União Européia e que a defesa do consumidor se faz necessária até mesmo como instrumento harmonizador da concorrência, veja, por todos, com estatísticas sobre o crescimento do setor turístico, Lete Achirica, Javier. El contrato de multipropriedad y la protección de los consumidores. Barcelona: Cedec, 1997, p. 32-34. 
interno e à competitividade internacional, assim como contribuem à criação de um mercado interno com concorrência leal e à realização das políticas governamentais. ${ }^{53}$

A tendência é a elaboração de regras nacionais, muitas consideradas de ordem pública internacional, ${ }^{54}$ lois de police ou leis de aplicação imediata, ${ }^{55}$ assim como a aproximação, harmonização das regras nacionais, que asseguram a proteção do consumidor, nos organismos internacionais dedicados à integração econômica, como a União Européia (UE) e o Mercosul.

B) Da necessidade de regras especiais de Direito Internacional Privado para a proteção dos consumidores também no Brasil

\section{Por um Direito Internacional} Privado com valores sociais $e$ função de harmonia regional

Os autores clássicos brasileiros conceituavam Direito Internacional Privado, na esteira de Pillet e da teoria francesa, como "a ciência que tem por objeto a regulação jurídica das relações internacionais de ordem privada" 56 ou as "relações de ordem privada da sociedade internacional", ${ }^{57}$ cujo objeto não seria apenas o estudo dos conflitos de leis no espaço, ${ }^{58}$ mas também os conflitos de jurisdição, os problemas de nacionalidade, condição jurídica do estrangeiro e direito adquirido. Particularmente, aceito a limitação do objeto do DIPr. proposta pelos autores italianos e alemães ${ }^{59}$ e neste trabalho considerarei Direito Internacional Privado as

53 Assim também Ghersi, Carlos Alberto, Razones y fundamentos para la integración regional. In: Ghersi, Carlos Alberto (Coord.). Mercosur: perspectivas desde el derecho privado. 1993 , p. 30 et seq.

54Veja Bucher, Andreas. L'ordre public et le but social de lois en droit international privé. Recueil des Cours, Haia, v. 2, n. 239, 1993, p. 60-69.

55 Veja sobre o art. 18 Lei de Dir. Internacional Privado suíça, Bucher, op. cit., p. 39.

56 Esta a definição de Fulgêncio, Tito, Synthesis de Direito Internacional Privado, Ed. Freitas Bastos, Rio de Janeiro, 1937, p. 5.

57 Esta a expressão de Bevilaqua, Clóvis, Princípios Elementares de Direito Internacional Privado, Ed. Histórica, Ed. Rio, 1988, p. 11.

58 Assim Rodrigo Octavio, Rodrigo, Direito Internacional Privado-Parte Geral, Ed. Freitas Bastos, Rio de Janeiro, 1942, p. 19, confessando que esta é a parte principal da disciplina, mas não a única, que segundo ele incluiria ainda a condição jurídica dos estrangeiros e o respeito aos direitos adquiridos, p. 20.

59 Kegel, Gerhard, Internationales Privatrecht, 6.ed., Beck, Munique, 1987, p. 3, Kropholler, Jan, Internationales Privatrecht, J. C. B. Mohr, Tübingen, 1990(Citado Kropolher/IPR), p. 1 e von Bar, Christian, Internationales Privatrecht-vol.II,BT, Beck, Munique, 1991, p. 1. 
regras, normas, o desenvolvimento jurisprudencial e os princípios tendentes a indicar uma lei aplicável aos casos privados com conexão com mais de uma ordem jurídica, solucionando apenas indiretamente os chamados conflitos de leis no espaço, assim como todas as normas (materiais, de ajuda, qualificadoras e de aplicação imediata) que intervêm ou ajudam (Hilsfnormen) neste procedimento. ${ }^{60}$ Os temas auxiliares para a solução destes conflitos de leis no espaço serão tratados aqui como matérias "irmãs" do DIPr. e, hoje praticamente e pragmaticamente nele contidas, como o Direito Processual Civil Internacional ou Processo Civil Internacional. Mas só poderei mencionar alguns dos esforços para a determinação de uma jurisdição especial para o consumidor e de facilidades no reconhecimento e execução de sentenças, bem como esforços para uma maior cooperação jurisdicional internacional neste tema, pois merecem um estudo epecial e monográfico, que expandirei este trabalho em demasia.

Da mesma forma, parece-me necessário esclarecer que aceitaremos aqui a teoria do Direito Internacional Privado pós-moderno de meu mestre de Heidelberg, prof, dr. dr. h.c. mult. Erik Jayme, para o qual o DIPr. é um instrumento de harmonia e paz nas relações hoje globalizadas. ${ }^{61} \mathrm{O}$ DIPr. pós-moderno conseguiria equilibrar e representar ao mesmo tempo as forças contraditórias sociais e econômicas de nossa época, do individualismo pósmoderno de uma identidade cultural exacerbada, à força irresistível da aproximação e regionalização econômica, de espaços supranacionais de integração e de um livre comércio globalizado. A proteção do consumidor se insere neste contexto como válvula de escape dos conflitos pós-modernos, pois representa juridicamente a garantia de um standard mínimo de segurança e adequação dos serviços e produtos, nacionais ou importados, comercializados nos mercados abertos de hoje. Representa, politicamente, um comprometimento com a lealdade do mercado, assegurada em visão macro pelo direito da concorrência e em visão micro, mas hoje cada vez mais coletiva e difusa, pelo direito do consumidor. Por fim, socialmente, procura equilibrar o revival da autonomia da vontade, da concentração no papel do indivíduo a determinar soberanamente suas relações privadas, econômicas e de consumo, e o revival dos direitos humanos, uma vez, que receber proteção do Estado é direito fundamental dos cidadãos de muitos países, e o direito do consumidor é direito humano de nova geração. ${ }^{62}$

\section{Veja art. $3^{\circ} \mathrm{da}$ EGBGB alemã.}

61 Assim os belíssimos ensinamentos de Jayme, Cours, p.56 e seg.

62 Jayme, Cours, p. 49. 
Se, como ensina Jayme, ${ }^{63}$ o DIPr. é um dos ramos mais sensíveis às mudanças sociais, políticas e jurídicas do final do século, pois evita conflitos ideológicos e valorações negativas quanto aos direitos nacionais, permitindo indicar soluções (materialmente e jusprivatisticamente) justas para os conflitos privados internacionais sem impedir ou afetar o curso do comércio internacional e do liberalismo econômico, inserir normas de respeito aos direitos do indivíduo neste DIPr. do futuro, não só minimiza os riscos de adoção de soluções radicais, pela insatisfação quanto à Justiça material nas relações internacionais, como também preenche uma lacuna da lex mercatoria ao estabelecer um standard internacional de garantia de efetividade de direitos para o parceiro mais fraco no comércio internacional, o consumidor, agente econômico leigo. Evita-se assim que a lacuna seja preenchida, pois, através de um novo territorialismo nacional radical.

Interessante notar que se os países sempre conseguiram um consenso sobre a necessidade de evoluir e garantir, com normas imperativas ou com normas narrativas (soft law), as bases do comércio internacional de mercadorias e serviços entre comerciantes ou profissionais, não houve até agora grande preocupação em evoluir as normas de DIPr. de proteção do consumidor-pessoa física, atuando fora de sua atividade profissional, como destinatário final de serviços e produtos para fins pessoais ou familiares. ${ }^{64}$ Fora os esforços da projetada Convenção de Haia em 1980 e as Convenções européias, o tema tem sido pouco debatido nas Américas como veremos. ${ }^{65}$ Se uma explicação pode ser tentada para esta lacuna consciente da lex mercatoria mundial, parece-me ser a de que os países desenvolvidos já possuem mecanismos jurídicos e de DIPr. suficientes para a aplicação de suas regras de defesa do consumidor, garantindo assim uma proteção efetiva de seus cidadãos também nas relações de consumo internacional.

Ao mesmo tempo, não há grande interesse ou necessidade de estender este mesmo standard para consumi-

63 Veja Jayme, Cours, p. 129 e seg.

64 Veja sobre o tema Arrighi, Jean Michel. La Proteccion de los Consumidores y el Mercosur, in: Revista Direito do Consumidor, São Paulo, vol. 2 (1992), p. 126 e seg.

65 Assim Toniollo, Javier Alberto. La protección internacional del consumidor - Reflexiones desde la perspectiva del Derecho Internacional Privado Argentino, in Revista de Derecho del Mercosur, ano 2, nr. 6, diciembre de 1998, p. 96, comentado o projeto de Haia. Veja também o mencionado relatório e projeto de VON MEHREN, Rapport explicatif-Loi applicable à certaines ventes aux consommateurs, in Actes et Documents de la Quatorzième session (1996), tome II, Ventes aux consommateurs, Buerau Permanent de la Conférence de la Haye, La Haye, 1982, p. 6 e seg. 
dores fora da região ou consumidores dos países de segundo e terceiro mundo, hoje países emergentes. Desenvolve-se então o mito, entre países emergentes, que um standard alto de proteção do consumidor representaria barreira ao livre comércio, ${ }^{66}$ desenvolvendo assim novos mercados para a colocação de produtos e serviços já proibidos em outros países ou ainda em fase de testes quanto aos seus riscos. Evita-se também que as indústrias locais dos países emergentes invistam no desenvolvimento de um standard internacional adequado de proteção do consumidor (e meio ambiente), de forma a impedir indiretamente que estas indústrias possam exportar seus produtos e serviços e participar mais ativamente (e concorrencialmente) do mercado internacional. Reverter este quadro, é problema de política internacional, mas o Direito pode contribuir preenchendo esta lacuna da maneira mais neutra e menos conflitual possível, que é, por ironia, o Direito Internacional Privado, com suas normas indiretas (ou de método conflitual) protetivas dos consumidores, com claro objetivo material (e não juridicamente neutro). ${ }^{67}$

Em resumo neste trabalho, propomos uma utilização atualizada do DIPr., preenchendo estas normas com valores sociais que oportunizarão a harmonia de relações internacionais necessária em nosso tempo; um DIPr. de solução material dos complexos conflitos pós-modernos que agora envolvem direitos humanos e limites constitucionais, ${ }^{68}$ um DIPr. "narrativo" 69 que vise, que "discurse" ao mesmo

66 Sobre a incorreção deste mito, veja meu artigo O Código de Defesa do Consumidor e o Mercosul, in Revista Direito do Consumidor, vol. 8 , p. 43 e seg.

67 Sobre a crise do DIPr., veja o curso de Kegel em Haia, citado por Nishitani, Yuko, Mancini und die Parteiautonomie im Internationalen Privatrecht, Universitätsverlag C.Winter, Heidelberg, 2000, p. 283.

68 Refiro-me ao Double Coding na interpretação das normas atuais, que não são mais intrinsecamente neutras, mas trazem em si a proteção dos valores constitucionais, especialmente os direitos humanos reconhecidos na ordem jurídica internacional, por Convenções de Direito Internacional Público. Veja Jayme, Cours, p. 36.

69 Adoto aqui a teoria de Jayme sobre normas narrativas (Jayme, Cours, p. 247), destacando que qualquer proposta de Convenção internacional e o texto daí oriundo tem hoje um efeito ao menos narrativo, de demonstrar os problemas e os caminhos, de narrar objetivos e princípios, mesmo que seja apenas como fonte de inspiração, mesmo que estas normas nunca cheguem a ter vigência, seus esforços, como os da Convenção de Haia de 1980, demonstram a existência de necessidades e forçam a procura - nacional, regional ou universal - de soluções. Veja sobre a necessidade de proteção internacional do consumidor os estudos de von Hoffman, Kropholler, nas Américas, de Boggiano, e mais recentemente de BRÖCKER e TONIOLLO, todos citados neste trabalho. 
tempo promova a "discussão," 70 que efetive a necessária proteção dos mais fracos nos mercados internacionalizados dos dias de hoje. ${ }^{71}$

Como prega Kropholler, em seu famoso artigo de 1978 sobre a proteção da parte mais fraca através do Direito Internacional Privado, ${ }^{72}$ é necessário evoluir para um DIPr. impregnado de valores sociais. Parece-me o momento para passar a considerar também nas normas de DIPr., como ensina Fausto Pocar, ${ }^{73}$ este valor: a proteção do mais fraco na sociedade de consumo e de informação, o consumidor.

Segundo Brilmayer os valores tradicionais do DIPr., tais como a previsibilidade da lei aplicável e o desencorajamento do forum shopping são análogos aos valores processuais, e não às conexões territoriais, pois não encontram seu fundamento em preferências materiais de cada país. ${ }^{74}$ Desenvolvendo um pouco mais este pensamento crítico da autora norteamericana, poderíamos afirmar, com Jayme, ${ }^{75}$ que as novas normas de DIPr. de proteção do consumidor, pelo menos as oriundas da União Européia têm finalidade material. Isto é, estas normas de DIPr. encontram seu fundamento nas preferências materiais e na decisão governamental supranacional de estender o standard europeu de proteção aos agentes econômicos mais fracos e de forma efetiva em toda a região, a todos os seus cidadãos e residentes.

Apesar de à primeira vista "nacionalista" (ou pós-nacionalista) esta opção material não me parece errada, pois em verdade o DIPr. continua à procura de uma legitimação material

70 Veja sobre o tema Müller, Friedrich, Direito-Linguagem-Violência, Ed. Sérgio Fabris, Porto Alegre, 1995, p. 17 e seg. Veja Habermas, Jürgen, Legitimation Crisis, Beacon Press, Boston, 1999,p. 68 e seg. e meu trabalho, A crise cientifica do Direito na pós-modernidade e seus reflexos na pesquisa, artigo publicado na Revista Arquivos do Ministério da Justiça, Brasília, ano 50, número 189, jan/junho 1998, p. 49 e seg., com extensa bibliografia sobre os efeitos descontrutores no Direito dos discursos da pós-modernidade.

71 Sobre a necessidade de tomada de posição da doutrina, veja incisivo, Arrighi, p. 126-127. 72 Kropholler, p. 655.

73 Veja seu curso de referência, Pocar, Fausto. La protection de la partie faible en droit internationl privé. Rec. Acad. La Haye, 1984, V, p. 339 et s.

74 Brilmayer, Lea, Conflits of Law, 2.ed, Little, Brown and Co., Boston, 1995, p. 178: "Traditional choice of law values such as predicability and the discouragement of forum-shopping are very closely analogous to procedural values. Unlike territorial scope decisions that derive from substantive preferences, however, they are typically not a product of specific domestic substantive rule, but apply across a wide range of substantive areas."

75 Assim manifestou-se sobre o fim material das normas de DIPr. oriundas da União Européia, Jayme (in Hommelhoff/Jayme/Mangold (Ed.), Binnermarkt-Internationales Privatrecht und Rechtsvergleichung (1995), p.35), apud Junker, p. 74, nota 132. 
para as suas opções de qual a lei a ser aplicada. Sendo assim, parece-me perfeitamente razoável que as conexões escolhidas pelo DIPr. para proteger o consumidor tenham como finalidade a proteção da parte mais fraca (von Hoffman), de seus direitos fundamentais (Jayme) e a justiça substancial no caso concreto (Zweigert). ${ }^{76}$

Doutrinadores norte-americanos de DIPr. destacam que o ideal de igualdade tem origem constitucional (The equal protection clause), ${ }^{77} \mathrm{o}$ que significa um limite para as normas de DIPr.: não devem elas de forma unfair discriminar, criar privilégios e imunidades, devem ser razoáveis e ter uma clara base social e política. ${ }^{78}$ Hoje, também podemos considerar este mandamento universal, mandamento de procura da igualdade entre as pessoas físicas de uma sociedade (o destacado por Jayme, revival dos direitos humanos na pósmodernidade): ${ }^{79}$ como um dos objetivos do DIPr., à procura da harmonia de decisões, ${ }^{80}$ da solução justa para os interesses envolvidos e para os direitos fundamentais envolvidos na relação de consumo. O DIPr. seria então mais um instrumento de proteção dos mais fracos e de realização da Justiça nestas sociedades internacionalizadas, integradas ou globalizadas.

Note-se que também em matéria de concorrência leal houve uma clara evolução em DIPr. As normas nacionais protetoras de concorrência leal atingiram forte grau de extraterritorialidade. ${ }^{81}$ Assim como os tratados europeus, ${ }^{82}$ também a tradicional conexão da lex loci delicti commissi passou a ser interpretada de forma flexível, seja como lugar da conduta concorrencial abusiva (place of wrongful conduct), seja o lugar do impacto (place of impact or relevant market), e até mesmo em ilícitos complexos passou o lugar da tomada de decisão da empresa a ser considerado, ${ }^{83}$ visando sempre

76 Assim concorda Toniollo, p. 99 citando De Vischer.

77 Herzog, Peter E., Constitucional Limits on Choice of Law, Recueil des Cours, 1992, III, t. 229, Nijhoff, Dordrecht, 1993, p. 285.

78 Herzog, p. 287.

79 Jayme, Cours, p. 167 e seg.

80 Assim Boggiano, Antonio, The Contribution of the Hague Conference to the Development of Private International Law in Latin America. Universality and genius loci, in Recueil des Cours, 1992, II, t. 233, Nijhoff, Dordrecht, 1993, p. 138.

81 Assim conclui, examinando o $\S 98,2,1$ GWB alemã, Martinek, Michael, Das internationale Kartellprivatrecht, Verlag Recht und Wirtschaft, Heidelberg, 1987, p.94.

82 Casella, Paulo Borba, Comunidade Européia e seu Ordenamento Jurídico, São Paulo, Ltr, 1994, p.430.

83 Sobre o tema e esta evolução em flexibilidade, veja DYER, Recueil, p. 413 e seg. 
a Justiça do DIPr. no caso concreto

e uma maior harmonia de decisões, ${ }^{84}$ em matéria contratual e extra-contratual.

Por fim, considere-se que em tempos de fragmentação pós-moderna, as regras de DIPr. devem concentrarse apenas em alguns temas, logo, assegurar também uma proteção em temas ou fragmentada. Devem ser regras flexíveis ou pelo menos alternativas para que o princípio do favorecimento do consumidor possa realizar-se. Segundo Jayme, o DIPr. pós-moderno deve privilegiar ao mesmo tempo os valores individuais, deixando que cada mercado de certa forma decida o que é melhor para seus consumidores. ${ }^{85}$ Esta fragmentação e flexibilização será tentada aqui através da concentração em dois temas, nos quais, parece-me, a proteção nacional do consumidor será sempre insuficiente e lacunosa, mesmo nos países de primeiro mundo, e onde a unificação de normas de DIPr. ${ }^{80}$ será oportuna também para o comércio internacional, ao criar maior segurança, previsibilidade para os profissionais e harmonia nas decisões, quais sejam alguns aspectos da proteção do turista e da proteção do consumidor no comércio internacional à distância ou através de meios eletrônicos.

\section{As conexões atuais das normas de conflito tradicionais e sua inadequação para a proteção do consumidor}

Segundo ensina Kropholler, ${ }^{87}$ é necessário elaborar normas específicas de DIPr. para a proteção dos consumidores leigos ou não profissionais, pois as conexões hoje existentes para regular o comércio internacional todas têm como base um equilíbrio estrutural de forças ou de interesses profissionais entre os agentes (ambos profissionais) envolvidos. Estas conexões, seja a autonomia da vontade (escolha da lei que regerá o contrato pelas partes, no contrato ou após), o local da execução (geralmente o local de execução da prestação característica, sempre prestada pelo profissional em caso de contrato de consumo internacional), ou do local de conclusão do contrato (conectando o contrato com a ordem jurídica do país do ofertante, em contratos à distância, sempre também o ofertante), não são adpatadas para os contratos de consumo, pois este equilíbrio estrutural inexiste nos contratos internacionais concluídos com consumidores leigos.

Segundo bem relembra Jayme, o momento atual é de prevalência de

84 Martinek, p. 96 .

85 Veja Jayme, Cours, p. 129 e seg.

86 Sobre os aspectos positivos e negativos da unificação do DIPr. através de Tratados, veja NEUHAUS, Paul Heinrich e Kropholler, Jan, Rechtsvereinheitlichung Rechstverbesserung?, in RabelsZ 45 (1981), p. 73 e seg.

87 Kropholler, p. 398 e seg. 
normas materiais em casos internacionais, reduzindo a importância do processo civil internacional tradicional. ${ }^{88}$ Tempos de uma maior possibilidade de determinação própria pelo indivíduo (Selbstbestimmung) em direito material, ${ }^{89}$ de novas técnicas nas convenções internacionais tentando harmonizar as diferenças culturais e de desenvolvimento através da cooperação judicial e respeito às normas imperativas locais, ${ }^{90}$ tentando respeitar os direitos humanos envolvidos no caso, ${ }^{91}$ o que significa, face à revolução tecnológica atual, uma nova prevalência pela residência habitual do consumidor como novo elemento de conexão para determinar a lei aplicável ao comércio internacional de conumo e novo critério para determinar a competência do foro. ${ }^{92}$ Aqui está, segundo o grande mestre de Heidelberg, o futuro do DIPr., a Jutiça do DIPr.

Alcançar objetivos materiais através de normas de DIPr. não parece propor um problema metodológico no DIPr. das Américas. Segundo muitos autores, há uma certa tradição de territorialismo na América Latina ${ }^{93}$ e também nos Estados Unidos, ${ }^{94}$ havendo claro privilégio hoje da aplicação da lex fori. Esta solução simplista da aplicação da lex fori sempre que relação de consumo ou relação considerada de ordem pública (internacional) é clássica, porém, não parece oportuna ou suficiente nos dias de hoje. ${ }^{95}$

88 Assim Jayme, Erik, Zum Jahrtausendwechsel: Das Kollisionsrecht zwischen Postmoderne und Futurismus, in IPRAX-Praxis des Internationalen Privat- und Verfahrensrechts, 2000, p. 169.

89 Jayme, IPRAX 2000, p. 170.

90 Assim Jayme, IPRAX 2000, p. 168.

91 Assim Jayme, IPRAX 2000, p. 171, citando os casos de decisão judicial na Alemanha sobre o desastre de Tschernobyl, em que o "local do delito" foi considerado o território alemão onde a "nuvem radiotiva" causou danos, que devem ser indenizados pela empresa russa e, também, os casos sobre comércio eletrônico, em que estão sendo considerados competentes os foros do local de "distribuição" da informação por internet, logo, do local onde está o consumidor.

92 Jayme, IPRAX 2000, p. 171.

93 Veja sobre as diferentes influências políticas e jurídicas para o territorialismo típico do DIPr. dos países da América Latina, Samtleben, Juergen, Menschheitsglück und Gesetzgebungsexport- Zu Jeremy Benthams Wirkung in Lateinamerika, in RabelsZ 50 (1986), p. 475. Veja também ARAÚJO, Nádia de, Contratos Internacionais - Autonomia da Vontade, Mercosul e Convenções Internacionais, $2^{\mathrm{a}}$ ed.,Ed. Renovar, Rio de Janeiro, 2000, p. 145 e seg.

94 Assim Richman, William M. e Reynolds, William L., Understanding Conflict of Laws2.ed., Times Mirror Books, USA, 1995, p. 230.

95 Assim também Kropholler, p. 635. 
Esta solução territorialista não é oportuna, pois não promove a harmonia de decisões e acaba por aumentar as tensões entre o comércio internacional, cada vez mais uniformizado e protegido, e as legislações nacionais ou regionais, que deixam desamparados seus consumidores, especialmente em países do terceiro mundo, possibilitando o abuso e o uso de standards fortemente diferenciados a criar, como afirma Gabriel Stiglitz, um consumidor de "resíduos", situação não sustentável a longo prazo. Esta solução territorialista não é suficiente, pois deixa sempre desamparados parte dos consumidores nacionais, pois nunca é suficiente para proteger o consumidor turista, nem protege eficazmente o consumidor atual, que contrata internacionalmente por telefone, cabo ou internet, sem precisa consciência de que lei se aplica a esta relação ou quais exatamente são seus direitos e garantias materiais, seus privilégios (ou não) de foro. De outro lado, há que se aprender com o ensinamento da Corte Européia, de tolerância e igualdade implícita dos ordenamentos jurídicos, das leis protetivas dos consumidores, principalmente entre Estados que participam de uma integração econômica e legislam sobre o standard mínimo. ${ }^{96}$ Assim como relembrar que muitas vezes a lei do outro país pode assegurar mais direitos ao consumidor do que a lei local..$^{97}$ Mister, pois, tentarmos usar todas as técnicas de flexibilidade, de abertura atual do DIPr. e ao mesmo tempo, as técnicas clássicas de segurança e limitada alternatividade para legitimar a melhor solução para o caso concreto privado internacional de consumo.

Esta mistura entre o atual DIPr. pós-moderno, posterior à American Revolution, ${ }^{98}$ e com valores sociais

96 Sobre o tema veja Bröcker, Marion, Verbraucherschutz im Europäischen Kollisionsrecht, Peter Lang, Frankfurt am Main, 1998, p. 107. Segundo a autora, a corte começou a estabelecer esta linha de igualdade valorativa (Gleichwertigkeit) das normas nacionais de proteção dos consumidores e de dever do Estado membro da União Européia de tolerância em relação à aplicação do direito "estrangeiro" de um país outro membro da União Européia justamente no caso Cassis de Dijon, BRÖCKER, p. 107.

97 Assim relembra Boggiano, Antonio, International Standard Contracts, Recueil des Cours, 1981, I, t. 170, Nijhoff, Dordrecht, 1982,p. 138, pleiteando a aplicação da lei mais favorável ao consumidor.

98 Segundo Erik Jayme (Jayme, Cours, p. 44), uma das tendências do direito internacional privado pós-moderno ou atual seria a materialização das regras de conflito de leis e aplicação reiterada da lex fori. Após a chamada "american revolution", movimento doutrinário e jurisprudencial ocorrido nos Estados Unidos na década de 1960, que repensou o método e a idéia de justiça no direito internacional privado, as regras de conflito de leis teriam superado seu automatismo e simples posição instrumental de indicação de uma lei material para resolver "diretamente" o conflito, passando agora a interessar-se pela solução concreta ou direta (material) do caso. 
claros, deve ser construída examinando o positivo e o negativo das conexões hoje existentes. Assim, por exemplo, se a autonomia de vontade das partes é hoje considerada o mais importante elemento de conexão no comércio internacional entre empresários, ${ }^{99}$ encontra ela um limite no que se refere às relações de consumo. Como ensina Neuhaus, a possibilidade de escolha da lei pelas partes, a autonomia da vontade em DIPr., perde seu sentido, se passa a ser instrumento de domínio dos mais fracos pelos mais fortes. ${ }^{100}$ Examinando a Convenção de Haia e a CIDIP IV, o mestre argentino Boggiano ${ }^{101}$ propôs para a proteção dos consumidores uma regra de limitada autonomia: a escolha das partes só prevaleceria se fosse esta a melhor lei, a lei mais favorável para o consumidor, devendo em caso contrário, aplicar-se a lei do domicílio do consumidor. Prevaleceriam como limites gerais à autonomia de vontade as normas de ordem pública internacional e as normas de polícia (art. 1208 CCArg.). ${ }^{102}$

A experiência européia é em sentido inverso, preferindo a Convenção de Roma indicar a preferência das normas imperativas do foro (art. $\left.7^{\circ}\right)^{103}$ e só depois uma norma especial limitadora - e em muito - da autonomia da vontade. A tendência autônoma internacional, porém, é de prestigiar a autonomia da vontade na escolha da lei aplicável aos contratos, mesmo que, por questões de política e de ordem pública, esta escolha seja limitada. ${ }^{104}$ A razão parece estar com Mancini, que, pleiteando a autonomia da vontade em DIPr., encontrava suporte desta justa-

99 De Boer, Ted. M., Facultative Choice of Law - The procedural status of choice-of-law rules and foreign Law, Recueil des Cours, 1996, t. 257, Nijhoff, The Hague, 1997, p. 300.

100 No original: "Die Parteiautonomie verliert ihren Sinn - ebenso wie die materiellrechtliche Vertragsfreiheit-, wenn sie zur Hersschaft des Stäerkeren über den Schwächeren wird.", Neuhaus, Die Grundbegriffe des IPR, 1962, p. 172 apud von Hoffmann, p. 396.

101 Veja, por todos, Boggiano, em seu texto The Contribuition, p. 138 e 139.

102 Boggiano, The Contribuition, p. 137.

103 Convenção de Roma de 1980- "Artigo $7^{\circ}$ - Disposições imperativas - 1. Ao aplicar-se, por força da presente Convenção, a lei de um determinado país, pode ser dada prevalência às disposições imperativas da lei de outro país com o qual a situação apresente uma conexão estreita se, e na medida em que, de acordo com o direito deste último país, essas disposições sejam aplicóveis, qualquer que seja a lei reguladora do contrato. Para se decidir se deve ser dada prevalência a estas disposições imperativas, ter-se-á em conta a sua natureza e o seu objecto, bem como as conseqüências que resultariam da sua aplicação ou da sua não aplicação. 2. $O$ disposto na presente Convenção não pode prejudicar a aplicação das regras do país do foro que regulem imperativamente o caso concreto, independentemente da lei aplicável ao contrato.

104 Assim a lei suíça de 1987, veja, em geral Nishitani, p. 291 e seg. 
mente no direito material, na liberdade (material) do indivíduo de vincular-se a um contrato que lhe seja justo e útil, estabelecer suas cláusulas e escolher a lei que será aplicada. ${ }^{105}$ Se hoje o DIPr. possui bases próprias para a escolha de elemento de conexão da autonomia da vontade, ${ }^{106}$ Neuhaus ${ }^{107}$ propõe que se inverta a idéia de Mancini: se as partes têm autonomia material de vontade, pode haver autonomia de vontade em DIPr., mas se as partes não têm verdadeira autonomia de vontade materialmente, porque uma parte é mais forte estruturalmente (como o profissional fornecedor que redige e determina $100 \%$ dos contratos internacionais de consumo) e outra mais fraca (o consumidor, leigo ou vulnerável que normalmente conclui contratos nacionais e somente, em algumas hipóteses, concluí contratos internacionais, às vezes sem mesmo se dar conta destas circunstâncias, então, não serve a autonomia de vontade como conexão principal do DIPr. Nestes casos, se não há verdadeira liberdade material, não pode haver verdadeira liberdade em DIPr. ou incentivaremos a escolha da lei mais favorável à (e pela) parte mais forte.

A posição de Boggiano, de uma limitada autonomia da vontade, estabelece em verdade uma conexão a "favor do consumidor", que pode ser interessante para a evolução do DIPr. da região. Certo é que os juízes brasileiros têm pouca tradição com normas alternativas abertas, mas a alternatividade limitada é um dos instrumentos mais usados hoje para garantir resultados materiais eqüitativos. ${ }^{108}$ A técnica de elaborar normas alternativas, indicando o fim material ou de favorecimento desejado, é mesmo denominada pela doutrina de Princípio do Favorecimento (Günstigkeitsprinzip) e são conhecidas as regras alternativas que levam ao favor negotii, favor matrimonii, favor legitimitatis, etc. ${ }^{109}$ A dificuldade com a regra proposta por Bogianno é a ainda ampla possibilidade de escolha da lei, o que significará grande trabalho para o juiz competente em verificar se aplicada a lei escolhida

105 Assim ensina Nishitani, p. 216 e pode-se ler nas perdidas aulas de Mancini, recuperadas e reproduzidas, em italiano, pela professora de Sendai, Nishitani, p. 378 e seg.

106 Assim Nishitani, p. 318.

107 Assim Nishitani, p. 318 citando a frase de Neuhaus: "Nur und überall dort, wo die erste [materiellrechtlicher Freiheit] besteht, ist auch die zweite [kollisionsrechtlicher Freiheit] angebracht." [Neuhaus, Die Grundbegriffe des IPR, 1962, p. 257] Assim também von Hoffmann, p. 396, citando Neuhaus.

108 Assim Kropholler, IPR, p. 120 (§ 20 II). Como esclare Nishitani, p. 283 estes novos métodos do DIPr. continental são conseqüência direta da American Conflicts Revolution emDIPr.

109 Assim ensina Kropholler, IPR, p. 120 a 122. 
seria esta melhor que a aplicação material das outras leis em contato com o consumidor.

Semelhante sugestão alternativa, mas mais limitada, fez Toniollo, defendendo que ao aplicar as regras argentinas o juiz procurasse uma harmonização com o mandamento de proteção do consumidor e permitisse ao consumidor (não ao juiz) escolher entre a aplicação da lei da residência habitual (art. 1209,1210,1212,1213 CCArg.), lex loci celebrationis (art. 1205 CCArg.) ou lex loci executionis, conforme a que fosse mais favorável a suas pretensões. ${ }^{110}$ Esta solução alternativa também é interessante, pois permite a escolha da lei mais próxima a esta relação de consumo, segundo a visão do consumidor. De outro lado, quanto maior a possibilidade de escolha do consumidor, menor a previsibilidade da lei a ser aplicável para o fornecedor, o que pode - se muito estendido - acabar prejudicando o comércio.

Note-se que Kropholler já considerava, em 1978, a determinação da lei mais favorável ao consumidor uma tarefa bastante difícil para os juízes, pois o uso desta conexão aberta, típica do atual Restatement dos Estados Unidos, pressupunha a comparação do resultado material da aplicação hipotética das várias leis envolvidas no caso, para só então determinar aquela mais favorável aos interesses do consumidor, e que seria aplicável. ${ }^{111}$ De outro lado, o hoje consagrado autor alemão, considerava que a progressiva harmonização das normas materiais a ser realizada pela Comunidade Européia iria diminuir a necessidade de normas especiais de DIPr., as quais, porém, continuariam necessárias em relações privadas envolvendo países terceiros, não euroupeus. ${ }^{12}$ Hoje, sabe-se que a evolução na harmonização das normas materiais apenas especifica a tarefa do DIPr. como instrumento de maior integração e não substitui estas normas, ${ }^{113}$ como comprovam as novas normas de DIPr. das Diretivas, da revisão da Convenção de Roma e mesmo do Direito autônomo alemão, que modificou o art. 29 da EGBGB de proteção do consumidor para incluir especificamente uma regra de preferência das leis materiais em alguns contratos (art. 29a EGBGB). ${ }^{114}$

110 Toniollo, p. 99: "Las elecciones alternativas son un adecuado instrumento de protección desde que permitan dejar de lado las legislaciones menos favorables, promoviendo teleologías."

111 Kropholler, p. 657.

112KrophollerR, p. 657.

113Assim também Toniollo, p. 108.

114A lei sobre contratação à distância com consumidores, aprovada em 13 de abril de 2000, introduziu este novo (e polêmico) art. 29a EGBGB, que entrou em vigor em $1^{\circ}$ de julho de 2000 (conforme noticia IPRAX, 2000, 3, p. [248] VI. Sobre os estudos de modificação do art. 29 para incluir o art. 29a na EGBGB, veja Staudinger, p. 414 e seg. O texto encontra-se também in IPRAX, 1999, 4, p. [304]VII. 
Correto, está, porém, Boggiano ao afirmar que as conexões rígidas fornecem para os nacionais apenas uma "segurança ilusória"," 115 pois hoje ninguém desconhece os fenômenos do forum shopping, das soluções alternativas de controvérsias e da desistência do consumidor de litigar internacionalmente (demanda reprimida). É assim pouco provável que, continuando o Brasil, no art. $9^{\circ}$ da LICC/ 1942, com conexões rígidas para os contratos de consumo, estas demandas venham a acontecer e ser solucionadas pelo juiz local. O DIPr. deve evoluir também em matéria de proteção do consumidor. Alerte-se que as normas que visam a proteção do consumidor são sempre representativas de um interesse estatal, regras imperativas. Desta natureza imperativa devem ser também as regras de DIPr. sugeridas. Em outras palavras, aqui não se está em uma matéria onde prevalece o interesse privado e comercial, onde a autonomia da vontade poderá decidir até mesmo a natureza da norma de DIPr., se obrigatória ou facultativa (facultative choice of law). ${ }^{116}$ Pela própria natureza desequilibrada da relação privada objeto das normas regionais propostas, o DIPr. para a proteção do consumidor aqui proposto deve ser um DIPr. imperativo e cogente para todos.

Mister superar as conexões tradicionais para proteger o contratante mais fraco. Por exemplo, a regra do favor offerentis, quanto à forma, e a conexão na residência do ofertante em contratos entre ausentes, conhecida no direito brasileiro, também são inadequadas para os desafios do comércio com consumidores e sua proteção nos dias de hoje. No caso de contratos ou relações de consumo, o ofertante é sempre o fornecedor (veja art. 30 Lei 8.078/90 brasileira), mesmo se fictamente denomina-se o contrato de adesão ou as condições gerais contratuais de "proposta" colocada a aceitação dos consumidores. Sabe-se que é o fornecedor que redige e determina tal "proposta", logo, tais formulários e a própria publicidade realizada pelo fornecedor ou profissional, determinam que a oferta de consumo seja, hoje, sempre realizada pelo fornecedor. ${ }^{17}$

Esta realidade faz com que as normas brasileiras atuais do art. $9^{\circ} \S 2^{\circ}$ da $\mathrm{LICC} / 42$ e art. $9^{\circ} \S 1^{\circ} \mathrm{LICC} / 42$

115 Assim Boggiano, The Contribuition, p. 134: "the illusion of rigid conflict rules". 116 Sobre o tema do DIPr. facultativo veja o curso de Haia de DE BOER, p. 235 e seg., em especial, p. 303 e seg.

117 No caso brasileiro, o CDC,Lei 8.078/90, determina expressamente que a oferta é sempre do fornecedor ou profissional ex vi lege nos art. 30, 34, 35 e 48. Veja meus comentários, in Contratos, p. 288 e seg. 
estejam superadas. ${ }^{118} \mathrm{O} \S 2^{\circ}$ do art. $9^{\circ}$ dispõe que a obrigação resultante do contrato reputa-se constituída no lugar onde residir o proponente, determinando assim a aplicação da lei do lugar de residência do fornecedor para reger os contratos entre ausentes, mesmo os de consumo. Necessário, pois, superar esta regra e escolher, para os contratos de consumo, diferentemente dos contratos internacionais comerciais uma conexão mais favorável ao consumidor, como a do art. $5^{\circ}$ da Convenção de Roma de 1980, que dá preferência à lei do país onde o consumidor tem sua residência habitual como conexão rígida (art. $5^{\circ}, 3$ Convenção de Roma de 1980), se não há expressa manifestação da vontade.

Este mesmo art. $5^{\circ}$ da Convenção de Roma de $1980^{119}$ determina que a eleição de uma lei para reger o contrato de consumo, isto é, a conexão na autonomia da vontade, não poderá excluir a aplicação das normas e leis imperativas de proteção do país de residência habitual do consumidor, se $a$ ) a oferta, publicidade ou algum ato de conclusão do contrato aconteceu neste país (por exemplo, a publicidade para um cruzeiro marítimo organizado na Argentina é feita na televisão aberta ou a cabo brasileira); b) se o fornecedor ou um seu representante receber a reserva ou realizar a contratação no país de residência habitual do consumidor (por exemplo, os contratos de multipropriedade no Uruguai, Punta del Este, com consumidores residentes no Brasil são celebrados no Brasil por representantes autônomos, que convidam os

118 O texto atual da LICC/42 é: "Art. $9^{\circ}$ - Para qualificar e reger as obrigações, aplicarse-á a lei do país em que se constituírem. $\S 1^{\circ}$. Destinando-se a obrigação a ser executada no Brasil e dependendo de forma essencial, será esta observada, admitidas as peculiaridades da lei estrangeira quanto aos requisitos extrínsecos do ato. $\S 2^{\circ}-A$ obrigação resultante do contrato reputa-se constituída no lugar onde residir o proponente."

119 O texto do artigo é: "Artigo $5^{\circ}$ - Contratos celebrados por consumidores - 1. Opresente artigo aplica-se aos contratos que tenham por objecto o fornecimento de bens móveis corpóreos ou de serviços a uma pessoa, o "consumidor», para uma finalidade que pode considerar-se estranha à sua actividade profissional, bem como aos contratos destinados ao financiamento desse fornecimento. 2. Sem prejuizo do disposto no artigo $3^{\circ}$, a escolha pelas partes da lei aplicável não pode ter como conseqüência privar o consumidor privado da protecção que lhe garantem as disposições imperativas da lei do país em que tenha a sua residência habitual: - se a celebração do contrato tiver sido precedida, nesse pais, de uma proposta que lhe foi especialmente dirigida ou de anúncio publicitário, e se o consumidor tiver executado nesse país todos os actos necessários à celebração do contrato, ou - se a outra parte ou o respectivo representante tiver recebido o pedido do consumidor nesse país, ou - se o contrato consistir numa venda de mercadorias e o consumidor, se tenha deslocado desse país a um outro país e aí tenha feito o pedido, desde que a viagem tenha sido organizada pelo vendedor com o objectivo de incitar o consumidor a comprar." 
consumidores para coquetéis e reuniões, lhe oferecem prêmios e vantagens, onde o empreendimento será explicado e a proposta assinada, assim como o pagamento futuro através de boletos de cartão de crédito que serão assinados também naquelas reuniões de venda em solo brasileiro); c) quando se tratar de venda de produtos e o consumidor viajar para adquirir estes produtos, mas a viagem for organizada pelo fornecedor com esta finalidade de contratação (por exemplo, excursões organizadas para adquirir produtos em uma zona franca ou em uma determinada fábrica no exterior), como esclarece o art. $5^{\circ}, 2$ da Convenção de Roma de 1980 sobre a lei aplicável às relações obrigacionais oriundas de contratos. ${ }^{120}$ No caso brasileiro, a melhor conexão rígida seria a do domicílio, entendido como residência habitual, a exemplo do art. $3^{\circ}$ do Protocolo de Santa Maria (Mercosul) ${ }^{121}$ ou da tradição das CIDIPs ${ }^{122}$ e suas normas materiais uniformes. ${ }^{123}$

Segundo Kropholler, as normas de proteção especiais de proteção dos consumidores, como agentes mais fracos no comércio internacional, deveriam seguir o seguinte método: respeitar a aplicação das normas imperativas (em alemão, Sonderregelung für zwingende Normen), ${ }^{124}$ elaborar normas por tipos contratuais ou temas, ${ }^{125}$ usar normas

120 Jayme, Erik e Hausamann, Rainer, Internationales Privat- und Verfahrensrecht, Beck Verlag, Munique, 1998, p. 116.

121 Araújo, Nádia, Marques, Frederico Magalhães e Reis, Márcio, Código do MercosulTratados e Legislação, Ed. Renovar, Rio de Janeiro, 1998, p. 161.

122 Segundo Siqueiros, José Luis, Contribucion de las CIDIP-I, II y III al Desarrollo del Derecho Internacional Privado, XIII Curso de Derecho Internacional, Secretaria General, OEA, 1987, p. 170. Esta foi uma das grandes contribuições das CIDIPS ao determinar que o domicílio interamericano aproximava-se da figura da residência habitual em voga na Europa, veja também CIDIP-II-1979- Convenção sobre o domicílio das pessoas físicas.

123 Como ensina Opperti Badan, Estado Actual del Derecho International Privado en el Sistema Interamericano, IX Curso de Derecho Internacional, vol. I, Secretaria General,OEA, 1983, nr. 2.7, a principal inovação da CIDIP-II sobre domicílio das pessoas físicas de 1979 foi a utilização de normas materiais uniformes. Segundo Almeida, Ricardo Ramalho, A convenção Interamericana sobre domicílio das pessoas fisicas em direito internacional privado, in Casella, Paulo Borba e Araujo, Nádia (Coord.), Integração Jurídica Interamericana- As Convenções Interamericanas de Direito Internacional Privado (CIDIPs) e o Direito Brasileiro, Ltr, São Paulo, 1998, as normas da referida CIDIP-II não são "substanciais", mas sim "qualificadoras", p. 217, ocorre que, na tradição germânica (veja Kropholler, p. 80, Kegel, IPR, 35, Steindorf, Ernst, Sachnormen im internationalen Privatrecht, Vittorio Klostermann, Frankfurt am Main, 1958, p. 30), as normas materiais de ajuda (Hilfsnormen), são consideradas normas materiais de DIPr (materielles Sonderrecht), logo, concordamos com a opinião do mestre uruguaio Opperti, Curso OEA, nr. 2.7.

124 Kropholler, op. cit., p. 648.

125 Ibidem, p. 655. 
bilaterais clássicas, ${ }^{126}$ optar por elementos de conexão objetivos, e, no caso dos contratos de consumo, optar por outra conexão do que a da prestação característica, ${ }^{127}$ dando preferência a conexões da esfera contratual do mais fraco (Recht der Vertragsphäre des Schwächeren), assim como limitar a autonomia da vontade ou possibilidade de escolha da lei por parte do fornecedor, comerciante ou parte contratual mais forte, ${ }^{128}$ e impor correções com cláusulas de ordem pública ${ }^{129}$ e cláusula escapatória, ${ }^{130} \mathrm{a}$ exemplo da atual lei suíça. Parece-me mais positivo utilizar o método da Convenção de Roma de 1980, de combinação entre a preferência das regras de aplicação imediata do foro (como o novo art. 29a EGBGB), com uma cada vez mais limitada possibilidade de escolha da lei.

Quanto às conexões tutelares, parece-me preferível no momento seguir o modelo do Mercosul, usado no Protocolo de Santa Maria específico de relações de consumo, e propor conexões rígidas para reger os contratos de consumo específicos, propondo uma regra alternativa limitada, a escolha do juiz da lei "favor consumidor", na regra geral para contratos de consumo. Assim, não resta muito espaço para a autonomia da vontade, neste primeiro momento, até mesmo para diferenciar da CIDIP V de 1994 e para estar atento às tendências protecionistas norte-americanas e tendências limitadoras atuais da experiência européia.

Kropholler termina sua análise afirmando que normas de DIPr. clássicas, com roupagem atual, poderiam servir para proteger o contratante mais fraco, que o DIPr. continental europeu poderia (e deveria) incluir valores e esta dimensão social, este era um mandamento (Gebote) de seu tempo. ${ }^{131}$ Concordando com esta afirmação e tomando em conta a visão pósmoderna do DIPr., segundo os ensinamentos de Erik Jayme, parece-me que hoje este é o mandamento ou Gebote para o Brasil, daí nossas sugestões na Parte II deste trabalho. Resta, porém, examinar os tratados regionais e verificar se são suficientes para a proteção dos consumidores.

126 Ibidem, p. 657 e 660.

127 Ibidem, p. 656.

128 Ibidem, p. 656.

129 Ibidem, p. 655.

130 Ibidem, p. 657.

131 Note-se que Kropholler, p. 660 , defende que a conexão mais estreita, determinada imperativamente por normas clássicas de DIPr. pode proteger eficazmente o consumidor, o contratante mais fraco, uma vez que as normas clássicas do DIPr. com roupagem atual podem absorver esta dimensão social de proteção dos mais fracos: "Das IPR Savignyscher Prägung nimmt die sozialen Gebote der Zeit in sich auf'. 


\section{A insuficiente proteção do} consumidor em DIPr. na LICC e nas convenções gerais sobre comércio de mercadorias

No Mercosul, a doutrina sempre alertou que, face às diferenças de nível de proteção nacional entre os quatro países, não poderia ser adotado o sistema de origem, ou se deixaria desprotegidos os consumidores dos países destinatários. ${ }^{132}$ A opção da Resolução do Grupo Mercado Comum n. 126/ 94, ${ }^{133}$ aprovada em 16 de dezembro de 1994, foi exatamente neste sentido, ao impor a regra do mercado de comercialização, no que respeita as normas aplicáveis de proteção dos consumidores, até que os esforços de harmonização legislativa dessem resultado positivo. ${ }^{134}$ Trata-se de norma específica de direito internacional privado unificado, visando a defesa do consumidor, ao determinar - indiretamente - qual a lei aplicável em caso de conflitos de consumo e ao impor a regra do país de destino: os produtos e serviços que circulam livremente no
Mercosul devem respeitar a lei do país onde serão comercializados, lei do mercado de destino, quanto à defesa do consumidor. Tal regra fixa assim um campo de aplicação espacial e territorial das normas nacionais de direito do consumidor $^{135}$ e recusa a regra européia de aplicação das leis do país de origem do produto ou serviço.

Se de um lado temos uma evolução bastante razoável na proteção material do consumidor por sua lei nacional, o mesmo não se pode dizer em matéria de proteção especial através do DIPr. Poderia se pensar que, como as normas nacionais de proteção dos consumidores são geralmente consideradas nos países como sendo de ordem pública internacional, lois de police ou normas imperativas do tipo "lei de aplicação imediata", não haveria necessidade de legislar sobre o tema: o consumidor domiciliado ou nacional de um país estaria sempre protegido pela aplicação provável destas normas. A conclusão não é suficiente, pois apresenta duas falhas:

1) Deixa o consumidor turista sem

132 Veja Dromi, p. 365. Assim também sempre propôs Stiglitz, El derecho del consumidor en Argentina y en el Mercosur, publicado na Argentina, La Ley,19/5/95 e no Brasil, in: Direito do Consumidor, vol. 6, p. 20.

133 MERCOSUL/GMC/RES. 126/94, in: Boletim de Integração Latino-Americana, 15, p. 133. 134 Resolución 126/94 GMC/Mercosur- "Art 2. Hasta que sea aprobado un Reglamento común para la defensa del consumidor en el Mercosur, cada Estado Parte aplicará su legislación de defensa del consumidor y reglamentos técnicos pertinentes, a los productos y servicios comercializados en su territorio."

135 Veja também Ciuro Caldani, Miguel Angel, Hacia la proteccion equilibrada del consumidor en el Derecho Internacional privado, in Investigación y docencia, 18, 1991, Rosario, p. 50. 
proteção quando retorna ao seu país, pois sua proteção pressuporia a extraterritorialidade destas leis, cuja característica é justamente a territorialidade. O consumidor turista nacional só estaria protegido quando o juiz nacional fosse aplicar justamente a lex fori a estas relações internacionais. ${ }^{136}$ Note-se, porém, que a maioria dos elementos de conexão hoje existentes nos países interamericanos é ou da autonomia da vontade em contratos internacionais, ou do lugar da execução ou do lugar de residência do proponente. Todas estas conexões mais comuns levarão à aplicação da lei estrangeira em relações contratuais com consumidores nacionais, pois é o fornecedor estrangeiro que redige os contratos concluídos com turistas, por exemplo, e inclui a cláusula de eleição da "sua" lei, também o lugar da execução é o da prestação caracterís- tica, que sempre é do fornecedor ou de país terceiro, por exemplo no comércio eletrônico de consumo, uma vez que o consumidor apenas paga o produto ou serviço. Hoje, também, ofertante é o profissional fornecedor, não mais os consumidores. ${ }^{137}$

2) Deixa o consumidor sem proteção, quando o foro provável de sua demanda for em país estrangeiro, por exemplo, quando contrata à distância ou por comércio eletrônico. Isto porque, não é cèrto que as normas imperativas ou de ordem pública do país de domicílio do consumidor serão aplicadas (se não houver uma Convenção Internacional específica) pelo juiz ou juízo arbitral do outro país, como comprovaram exaustivos estudos da jurisprudência do primeiro mundo. ${ }^{138}$

Interessante observar que à exceção dos Estados Unidos ${ }^{139}$ e Canadá, raras são as normas nacionais

136 Veja Resp. 63.981-SP, cujo relator foi o min. Sálvio de Figueiredo, foi decidido em 4 de maio de 2000. Veja meus comentários no artigo Normas, in Revista de Direito Privado 4, p. 85 e seg.

137 Veja que a prestação característica não foi considerada oportuna, nem mesmo para inclusão na CIDIP V, assim Noodt, Taquela, Maria Blanca, Convención interamericana sobre Derecho aplicable a los contractos internationales, in El Derecho internacional privado interamericano en el umbral del siglo XXI, Diego Fernandez Arroyo (Org.) Ed. Eurolex, Madri, 1997, p. 104.

138 Após exaustivo exame do direito e da jurisprudência alemã, chegou à conclusão de que não há obrigação alguma do juiz alemão de usar as normas imperativas de terceiros países, somente as normas imperativas dos países membros da UE devem ser respeitadas, face ao art. $7^{\circ}$, I da Convenção de Roma de 1980, assim BECKER, Michael, Zwingendes Eingriffsrecht in der Urteilsanerkennung, in RabelsZ 60 (1996), p. 737.

139 Veja art. 3.545 sobre products liability e art. 3.547 sobre conventional obligations da nova lei da Louisiana, Lei 923 de 1991 (publicada na íntegra in IPRAX 1993, p. 56 e seg), in Kropholler, Jan, Krüger, Hilmar, Riering, Wofgang, Samtleben, Jürgen, Siehr, Kurt, Aussereuropäische IPR-Gesetze, Max-Planck-Insitut, Hamburg, 1999, p. 1002 e seg. 
de Direito Internacional Privado que se voltam especificamente para a proteção dos consumidores nos países Americanos. Quanto ao DIPr. do Quebec, positivado no Código Civil de 1991, interessante observar sua atualização metodológica, porque prevê várias normas abertas (art. 3076), o conhecimento de leis imperativas de outro Estado (art. 3079), uma ordem pública estrita pela incompatibilidade do resultado prático da aplicação da lei estrangeira (art. 3081) e uma cláusula escapatória geral (art. 3082). ${ }^{140}$ Assim como possui uma regra específica para os contratos de consumo (art. 3117), ${ }^{141}$ permitindo a autonomia de vontade, mas considerando obrigatórias as normas imperativas do foro, em idênticas circunstâncias que o art. $5^{\circ} \mathrm{da}$ Convenção de Roma e indicando, na falta de escolha, a lei da residência do consumidor como aplicável.

O Código Civil do Quebec possui regra específica também para acidentes envolvendo produtos (art. 3128), prevendo que a vítima (não se menciona a expressão consumidor) poderá escolher entre a lei do Estado em que o fabricante do produto tem seu estabele- cimento ou sua residência e a lei do Estado onde o bem foi adquirido, além de considerar as suas normas de DIPr. imperativas para qualquer dano sofrido no Quebec ou resultante de matéria prima oriunda do Quebec (art. 3129).

Por exemplo, a lei de proteção ao consumidor da Venezuela é de $1995 .{ }^{142}$ A nova lei venezuelana de Direito Internacional Privado é posterior e data de 1998, mas, em seus 64 artigos, nada menciona especificamente sobre proteção do consumidor, apesar de várias vezes mencionar os princípios generales del Derecho Comercial Internacional. Mesmo assim, a nova lei venezuelana traz normas atualizadas sobre a aplicação das normas imperativas nacionais (art. 10), sobre a conexão eqüitativa para o caso concreto (art. $7^{\circ}$ ) e, especialmente, traz uma norma de favor vítima em caso de acidentes ou atos ilícitos, o que pode beneficiar os consumidores (art. 32). ${ }^{143}$

Nos países membros do Mercosul, a situação não é melhor. No Paraguai, a lei de defesa do consumidor é de $1998,{ }^{144}$ já o Código Civil de 1985 nada menciona sobre consumidores e, em matéria contratual, indica aplicável a lei

140 Veja texto in Dolinger, Jacob, e Tibúrcio, Carmen, Vade-Mécum de Direito Internacional Privado, Ed. Renovar, Rio de Janeiro, 1994, p. 297-298.

141 Veja texto in Dolinger, Vade Mecum, p. 297-298.

142 Publicada na íntegra, no Brasil, in Revista Direito do Consumidor, vol. 26(1998), p. 307-327. 143 Veja Decreto 36.511, de 6 de agosto de 1998, in Kropholler/Krüger/Riering/Samtleben/ Siehr, p. 958-995.

144 Ley 1.334, 27 de outubro de 1998, a ser publicada na íntegra. Revista Direito do Consumidor, vol. 30 (1999), p. 247-255. 
do lugar da execução da obrigação (art. 17). ${ }^{145}$ No Uruguai, sua lei de defesa do consumidor é de 1999, ${ }^{146}$ seu Código Civil de 1868, modificado em 1994, indica aplicável para relações obrigacionais a lei do lugar da execução (art. 2.399) e os Tratados de Montevidéu de 1889. ${ }^{147}$

Já no Brasil, as normas brasileiras de DIPr. são rígidas e antigas, também nada mencionam sobre consumidor e prevêem apenas uma ampla regra sobre ordem pública (art. 17 da Lei de Introdução ao Código Civil Brasileiro, LICC/42). Em matéria contratual, apesar dos esforços da doutrina; as normas atuais praticamente impossibilitam a autonomia de vontade em matéria de contratos. ${ }^{148}$ Aplicável neste caso é a lex loci celebrationis (art. 9० caput da LICC/42: "Para qualificar e reger as obrigações, aplicar-se-á a lei do país em que se constituirem"). A norma do art. $9^{\circ} \S 1^{\circ}$ LICC/42 impõe uma aplicação cumulativa de lei brasileira quanto à forma, em caso de execução no Brasil. A norma do art. $9^{\circ} \S 2^{\circ}$ da LICC/42 é usada para identificar o lugar da proposta em contratos entre ausentes ou à distância, como a maioria dos contratos internacionais nos dias de hoje. Segundo o $\S 2^{\circ}$ do art. $9^{\circ}$, a obrigação resultante do contrato reputa-se constituida no lugar onde residir o proponente, determinando assim a aplicação da lei do lugar de residência do fornecedor para reger os contratos entre ausentes, mesmo os de consumo, como os contratos concluídos por computador, no comércio eletrônico de consumo, ou nos contratos de timesharing ou multipropriedade. Em matéria de acidentes com produtos e serviços defeituosos a regra aplicável também é a do art. $9^{\circ}$, agora interpretada como lex loci delicti, lei do lugar em que foi cometido o ato ilícito ou lei do lugar em que aconteceu o dano e suas conseqüências. ${ }^{149}$

A doutrina argentina sempre propôs normas especiais mais protetivas para

145 Kropholler/Krüger/Riering/Samtleben/Siehr, p. 638.

146 Ley 17.189, de 20 de setembro de 1999, publicada na íntegra. Revista Direito do Consumidor, vol. 33 (2000), p. 262-270.

147 Kropholler/Krüger/Riering/Samtleben/Siehr, p. 910.

148 Ver, por todos, Araújo, p. 108. Sobre a controvérsia da autonomia da vontade no Brasil e em vários países da América Latina e a contribuição dada pela CIDIP e pelas Convenções de Haia, veja Boggiano, The Contribuition, p. 132 e seg.

149 Sobre esta versão brasileira da teoria da ubiqüidade alemã e as críticas da doutrina a estas conexões rígidas, veja Marques, Claudia Lima, Novos rumos do Direito Internacional Privado quanto às obrigações resultantes de atos ilícitos (em especial de acidentes de trânsito), in Revista dos Tribunais, São Paulo, vol. 629 (mar/1988), p. 72 e seg. 
as relações de consumo, especialmente para os contratos de adesão. ${ }^{150}$ Quanto ao âmbito contratual, que mais nos interessa, as normas nacionais ou autônomas de DIPr. argentino encontram-se nos art. 1205 a 1214 do Código Civil e não há normas especiais para a proteção dos consumidores, mas o novo mandamento constitucional deve "iluminar" a aplicação destas normas. ${ }^{151}$ Os artigos 1209 e 1210 prevêem a aplicação da lex loci executiones e da lex loci celebrationes, mas a doutrina alerta que, em uma visão tradicional, a primeira conexão vai indicar aplicável geralmente a lei do fornecedor, aquele que realizou a prestação principal característica, isto é, a prestação não vinculada ao pagamento de dinheiro realizado pelo consumidor, cons- tituindo "injustificado privilégio" ao fornecedor. ${ }^{152}$ A segunda conexão beneficia a aplicação da lei do lugar de "assinatura" dos contratos, levando muitas vezes à aplicação da lex fori argentina, mas deixa sem proteção o consumidor turista e aquele que contrata à distância ou por meios eletrônicos, situações cada vez mais comuns nos dias de hoje. ${ }^{153}$ A doutrina propõe então que o consumidor possa eleger entre a ley del lugar de adquisisión del producto, que seria especialmente importante nos dois casos mencionados, e uma conexão para a lei mais favorável ao consumidor, assim como a elaboração de normas semelhantes ao art. $5^{\circ}$ da Convenção de Roma de $1980 .{ }^{154}$ Já quanto aos atos ilícitos frente aos consumidores, a conexão tradicional é também na Argentina a lex loci delicti (art. 43 do Tratado de Montevidéu de 1940), entendida como lei do lugar do ato delituoso (lex loci actus), mas já sofre severas críticas e sugere-se que, em relações de consumo, possa-se usar a lei da residência habitual de quem sofreu o dano, em solução semelhante à Convenção de Haia de 1973. ${ }^{155}$ Parte da doutrina propõe que o consumidor vítima possa eleger entre a lei do lugar do estabelecimento principal da pessoa a quem vai se atribuir a responsabilidade e a lei do lugar de aquisição do produto. ${ }^{156}$

Se a legislação nacional ainda é falha neste setor, na doutrina do DIPr.,

150 Assim o famosos curso de Haia de Boggiano, International, p. 55 e The Contribuition, p. 134 e seg.

151 Toniollo, p. 98.

152 Assim Toniollo, p. 100.

153 Assim alerta também, Toniollo, p. 102.

154 Toniollo, p. 101, 102 e 107.

155 Toniollo, p. 108 e 110.

156 Sugestão de Toniollo, p. 110. 
cada vez mais o tema da proteção dos consumidores é incluído como matéria de nova concentração do Direito Internacional Privado. ${ }^{157}$ A doutrina é praticamente unânime na necessidade de proteção especial do consumidor também em relações de consumo internacionais e na decisão regional a favor do consumidor. A autonomia de vontades é regra não oportuna se uma das partes é mais fraca, como no caso de contratos concluídos com consumidores. ${ }^{158}$ Propõe-se assim uma harmonização das regras de DIPr. através do Mercosul ${ }^{159}$ e de outros organismos internacionais. ${ }^{160}$ Também em processo civil internacional os desafios da globalização e regionalização da economia estão a requerer uma reposta efetiva de proteção dos mais fracos com jurisdições privilegiadas e soluções alternativas de controvérsias.

Importa-nos aqui relembrar que as grandes convenções sobre comércio internacional sempre procuraram excluir do campo de aplicação de suas normas os contratos concluídos com consumidores para uso doméstico, familiar ou não profissional. ${ }^{161}$ Assim a Convenção de Haia ${ }^{162}$ sobre a lei aplicável aos contratos de compra e venda internacional de 1986 (art. $2^{\circ}$, lit.c e $5^{\circ}$, lit. d) $)^{163}$ ou a Convenção da ONU sobre Compra e Venda de Mercadorias de 1980, conhecida como Convenção de Viena de $1980^{164}$ (art. $2^{\circ}$, a e

157 Boggiano, The Contribuition, p. 139, Toniollo, p. 94 e seg., Marques, Cláudia Lima, Direitos do Consumidor no Mercosul : Algumas sugestões frente ao impasse, in Revista Direito do Consumidor, São Paulo, vol. 32 (1999), p. 16 e seg. Já Brilmayer, p. 174, inclui tópico "The postulate of Consumer Sovereignity" não para tratar da proteção do consumidor, mas para realizar analogia à soberania de decisões dos estados de quais politicas (policy) ou interesses protegerão em DIPr, seguindo a linha do Law and Economics.

158 Veja Boggiano, International, p. 55 e seg. e Boggiano, The Contribuition, p. 138.

159 Veja por todos Toniollo, p. 97.

160 Boggiano, The Contribuition, p. 138, trabalha com a possibilidade de uma manifestação geral através da Conferância de Haia ou regional, através da OEA.

161 Assim Hargain/Mihali, p. 506.

162 Trata-se de uma atualização da Convenção de 1955. Veja sobre a pequena aceitação destas Convenções entre os Estados, mas de sua enorme importância como modelo legislativo, in Araújo, p. 124 e seg.

163 No original: "Art.2. The Convention does not apply to: ....c) sales of goods bought for personal, family or household use; it does, however, apply if the seller at the time of the conclusion of the contract neither knew nor ought to have known that the goods were bought for any such use. Art. 5. The Convention does not determine the law applicable to ...d) the effect of the sale in respect of any person other than the parties."

164 Veja sobre a importância e a aceitação desta Convenção também entre Estados das Américas, Araújo, p. 127 e seg. 
art. $\left.5^{\circ}\right) .{ }^{165}$ Seja para evitar conflitos com leis nacionais consideradas de ordem pública internacional, ${ }^{166}$ seja porque as diferenças na proteção dos consumidores sempre pesaram a favor dos países industrializados e exportadores do primeiro mundo. ${ }^{167} \mathrm{~A}$ verdade é que o tema nunca foi tratado diretamente nas convenções ${ }^{168}$ que unificaram as normas materiais, nem em uma lei modelo, do UNIDROIT ou UNCITRAL, ${ }^{169}$ nem foi objeto de uma CIDIP ou de uma Convenção de Haia. ${ }^{170}$ Apenas as Resoluções da ONU tiveram influência inspiradora nas legislações nacionais.

O tratamento jurídico de relações entre iguais não pode ser igual ao tratamento jurídico de relações entre diferentes, entre profissionais e leigos,

165 No original o art. $2^{\circ}$ da Convenção de Viena de 1980 dispõe: "Esta convenção não se aplica às vendas: a) de mercadorias adquiridas para uso pessoal, familiar ou doméstico, salvo se o vendedor, antes ou no momento da celebração do contrato, não soubesse nem devesse saber que as mercadorias eram adquiridas para tal uso".

166 Assim manifestam-se Garro/Zuppi, p. 81: "La razón principal de excluir la venta a consumidores del ámbito de aplicación ha sido de evitar un eventual conflicto entre las normas de la Convención y las leyes de orden público de protección al consumidor. La legislación especial de protección al consumidor ha sido incorporada en estos últimos años a numerosos ordenamentos jurídicos, inclusive en algunos países de América Latina, como México." Assim também Hargain/Mihali, p. 507.

167 Assim Hoffmann, p. 396, Kropholler, p. 636, Botana, p. 9 e Hargain/Mihali, p. 506, citando opinião de Lible.

168 Teriam ratificado a Convenção, até 1995, os seguintes países interamericanos, Argentina, Chile, Ecuador, Canadá, Cuba, México e Estados Unidos, e assinado, Venezuela. Veja Schlechtriem, Peter, Internationales UN-Kaufrecht, J.C.Mohr, Tübingen, 1996, p. 225-226 ou para dados atualizados: www.un.org/Depts/Treaaty/bible/Part_I_E/X_/X_10.html.

169 A lei modelo da UNCITRAL (que efetivamente se dedica ao comércio internacional) versando sobre comércio eletrônico expressamente informa não afastar as normas tutelares e parece querer excluir os contratos de consumo através de meios informáticos de seu campo de aplicação com o texto: “Art. 1. Ámbito de aplicación - La presente Ley* será aplicable a todo tipo de información en forma de mesaje de datos utilizada en el contexto de actividades comerciales. ${ }^{*}$ La presente ley no deroga ninguna norma jurídica destinada a la protección del consumidor."

170 Mencione-se o projeto de Haia de 1980. Veja Von Mehren, Arthur, Law applicable to certain consumer sales, Texts adopted by the Fourteenth Session and Explanatory Report, Ed. Bureau Permanent de la Conférence, Haia, 1982, p. 6. Este projeto de convenção visava complementar a Convenção de Haia de 1955 sobre lei aplicável à venda internacional de mercadorias, mas isto nunca chegou a acontecer, pois o referido projeto, findo em 1980, não foi aprovado, superado que foi pela própria Convenção de Roma da CEE, assinada naquele mesmo ano, com seu art. $5^{\circ}$ sobre o mesmo tema. 
entre fortes e fracos. Esta foi justamente a idéia central do Projeto de Haia de 1980, que foi superado pelas convenções européias e as modificações internas nos países industrializados, mas não no espaço interamericano. ${ }^{171} \mathrm{~A}$ experiência européia de mais de 40 anos de harmonização de normas materiais e unificação de normas de DIPr. e do art. $2^{\circ}$ da Convenção de Viena de 1980 , nos faz concluir que tanto regionalmente, como universalmente, a proteção do consumidor sempre foi tema a separar-se do comércio internacional normal e a tratar-se em DIPr. com conexões mais seguras, previsíveis e positivas para o agente mais fraco. Concluo, portanto, pela oportunidade de se elaborar norma epecial sobre o tema.

\section{SUGESTÕES PARA A NOVA LEI DE INTRODUÇÃO AO CÓDIGO CIVIL BRASILEIRO NO QUE SE REFERE À LEI APLICÁVEL A ALGUNS CONTRATOS E
ACIDENTES DE CONSUMO}

Efetivamente, conhece o Direito Internacional Privado brasileiro as denominadas "normas de aplicação imediata", espécie das normas imperativas, que perseguindo um resultado material de Justiça do Direito Internacional Privado, aplicam-se aos casos pluriconectados de forma "direta" antes mesmo da norma indireta, da norma de conflito que indicaria uma lei para regular materialmente o caso concreto. ${ }^{172}$ A pergunta é se todas as normas de

171 Note-se que as conexões previstas pelo projeto de Haia de 1980 foram: a autonomia da vontade (art. $6^{\circ}$, frase 1), mas a lei escolhida pelas partes não poderia privar o consumidor da proteção que lhe asseguram as normas imperativas do país de sua residência habitual (art. $6^{\circ}$, frase 2 do projeto), as condições relativas à existência, à validade e à forma do consentimento seriam regidas pela lei do país de residência habitual do consumidor no momento da declaração. (art. $6^{\circ}, 4$ frase), na falta de escolha pelas partes, a lei aplicável seria a lei do país de residência habitual do consumidor (art. $7^{\circ}$ do projeto), a capacidade das partes e os efeitos dos contratos não seriam regidos pela lex contractus e sim tratados como questões independentes (art. $9^{\circ}$ ) e a reserva de ordem pública, veja Von Mehren, Arthur, Law applicable to certain consumer sales, Texts adopted by the Fourteenth Session and Explanatory Report, Ed. Bureau Permanent de la Conférence, Haia, 1982, p. 2 e 3. A definição de consumidor (art. $2^{\circ}$ ) e as exclusões (art. $4^{\circ}$ e $5^{\circ}$ ) do projeto não são hoje, porém, atuais, mesmo assim em um exame mais detido do projeto de 1980 encontramos muitos dos elementos até hoje desejáveis em matéria de proteção efetiva dos consumidores em DIPr.

172 Assim Marques dos Santos, António. As normas de Aplicação imediata no Direito Internacional Privado - Esboço de uma Teoria Geral- vol. I, Coleccão de Teses, Ed. Almedina,Coimbra, 1991, p. 11. Veja também Schwander, Ivo, Lois d'application immédiate, Sonderanknüpfung, IPR-Sachnormen und andere Ausnahmen von der gewöhnlichen Anknüpfung im internationalen Privatrecht, Schulthess, Zurique, 1975, p. 132-184. 
defesa do consumidor, por exemplo, as presentes no Código de Defesa do Consumidor, que é norma de ordem pública interna (ex $v i$ art. $1^{\circ}$ da Lei 8.078/90) seriam normas de aplicação imediata, a afastar o exame do atual art. $9^{\circ} \mathrm{da} \mathrm{LICC} / 42$ ou se deveríamos sugerir normas especiais de proteção dos consumidores em DIPr. Vejamos.

\section{Consumidor, o agente} esquecido na LICC: leis de aplicação imediata ou necessidade de uma norma especial para a proteção contratual dos consumidores

A globalização, a aproximação dos mercados, a integração de mercados, a abertura para produtos e serviços estrangeiros, a internacionalidade das relações privadas são, segundo doutrina atual, os grandes desafios do direito do consumidor. ${ }^{173}$ Segundo as palavras lúcidas de Jean-Michel Arrighi o consumidor, nesta aproximação de mercados, é, também nas leis nacionais, o "protagonista olvidado". ${ }^{174}$

As chamadas "leis de aplicação imediata", na definição clássica de
Franceskakis, são leis ou regras "cuja observação é necessária para a salvaguarda da organização política, social ou econômica de um país."175 Esta técnica de regulação direta do Direito Internacional Privado, de identificar algumas leis ou normas internas, que por sua importância e íntimo contato com os interesses governamentais ou a ordem pública de um país, devem ser seguidas por todos e em todas as relações privadas com contatos fortes com aquele país, ${ }^{176}$ Estas normas aplicam-se imediatamente para nacionais e estrangeiros e para todas as relações privadas, sem necessidade de antes passar pelo método de DIPr. de indicação de uma lei aplicável. Em outras palavras, esta lei "de aplicação imediata" ou lei de "polícia" tem pretensões de aplicação genérica e extraterritorial sempre, não importando se são leis de direito privado ou público, uma vez que positivam fortes interesses de organização da sociedade estatal.

Como a chamada lei de aplicação imediata é direta ou resolve o conflito diretamente, sua aceitação e identificação hierárquica dentro do DIPr. é

173 Assim também Macedo Júnior, p. 45 e 53.

174 Arrighi, p. 126.

175 No original: "don't l'observation est nécessaire pour la sauvegarde de l'organisation politique, sociale ou économique du pays.", citado por Bucher, p. 39. Veja art. $7^{\circ}$, alinea 2 da Convenção de Roma da UE sobre lei aplicável às obrigações contratuais de 1980. Tais normas se aplicam diretamente. Veja sobre o art. 18 Lei de Dir. Internacional Privado suíça, Bucher, p. 39.

176 Veja detalhes no Cap. 6, que escrevi para o livro, Derecho Internacional Privado de los Estados del Mercosur, Org. Diego Fernandez Arroyo, Zavalia, Buenos Aires, 2003, p. 300 e seg. 
uma técnica (por sinal cada vez mais usada) de "materialização" das novas regras de conflitos de leis. ${ }^{177}$ Este fenômeno geralmente é conhecido pela expressão francesa lois d'application immédiate, popularizadas pelos estudos do grande professor grego Franceskakis desde 1958, apesar do estudo muito semelhante do italiano De Nova (norme sostanziali autolimitate, norme di applicazione necessaria), datar de 1959. ${ }^{178}$ A segunda expressão francesa, lois de police ou leis de polícia, também ficou mais conhecida do que a expressão alemã, a significar leis obrigatórias, zwingende Normen (na expressão de Savigny: Gesetzen von streng positiver, zwingender Natur). ${ }^{179}$

Assim, por exemplo, o art. $3^{\circ}$ do Código de Defesa do Consumidor inclui como fornecedor submetido às normas imperativas do CDC toda pessoa fisica ou juridica, pública ou privada, nacional ou estrangeira, bem como os entes despersonalizados, que desenvolvam atividade de produção, montagem, criação, construção, transformação, importação, exportação, distribuição ou comercialização de produtos ou prestação de serviço. Mencionados expressamente também no art. 12 do CDC estão os fabricantes, produtores e construtores estrangeiros e o importador de produtos estrangeiros. É interessante relembrar que as normas do CDC são de ordem pública interna (art. $1^{\circ}$ ), e que os artigos $2^{\circ}$ e $3^{\circ}$ do Código de Defesa do Consumidor denotam sua aplicação a todos os consumidores finais, nacionais ou estrangeiros (independente de sua nacionalidade ou domicílio) e fornecedores, nacionais e estrangeiros. Assim, dispõe o CDC, em espírito de inclusão semelhante ao do revogado art. $3^{\circ}$ do Código Civil de $1917,{ }^{180}$ e com espírito de real proteção do vulnerável, sem mencionar a nacionalidade ou o domicílio dos agentes: art. $2^{\circ}$ Consumidor é toda pessoa fisica ou jurídica que adquire ou utiliza produtos ou serviços como destinatário final. Parágrafo único. Equipara-se a consumidor a coletividade de pessoas, ainda que indetermináveis, que haja intervindo nas

177 Jayme, Hague Cours, 1995, p. 44.

178 Assim Marques dos Santos, António. As Normas de Aplicação Imediata no Direito Internacional Privado - Esboço de uma Teoria Geral- vol. I, Coleção de Teses, Ed. Almedina, Coimbra, 1991, p. 11 e seg.

179 Veja, por todos, Schwander, Ivo, Lois d'application immédiate, Sonderanknüpfung, IPR-Sachnormen und andere Ausnahmen von der gewöhnlichen Anknüpfung im internationalen Privatrecht, Schulthess, Zurique, 1975, p. 132 a 184.

$180 \mathrm{O}$ art. $3^{\circ}$ do $\mathrm{CCBr}$. atual dispõe: "A lei não distingue entre nacionais e estrangeiros quanto à aquisição e ao gozo dos direitos civis." Infelizmente este artigo não foi repetido pelo novo Código Civil brasileiro aprovado em 10.01.2002. 
relações de consumo. $\mathrm{E}$ o art. 29 complementa: Para os fins deste capitulo e do seguinte, equiparamse aos consumidores todas as pessoas determináveis ou não, expostas às práticas nele previstas. Em matéria extracontratual, a inclusão - para proteção - de todos os consumidores, contratantes ou não, é clara, no art. 17, no capítulo referente à responsabilidade pelo fato do produto ou serviço: art. 17. Para os efeitos desta seção, equiparamse aos consumidores todas as vítimas do evento.

Todos estes artigos bem denotam a "vontade" do Código de Defesa do Consumidor em aplicar-se também a casos de consumo internacional ocorridos no mercado brasileiro ou com os consumidores que protege. Pareceme, pois, em uma primeira análise, tratar-se de uma lei de aplicação imediata. ${ }^{181}$ Efetivamente, parte da doutrina defende que o Código de Defesa do Consumidor deve se aplicar a todos os contratos do consumidor com contatos suficientes ao Brasil, enquanto uma regra imperativa internacional ou lois d'application immediate. ${ }^{182} \mathrm{O}$ Código de Defesa do Consumidor deve fornecer padrões mínimos (e imperativos) à proteção de consumidores-passivos em todos os contratos à distância, contratos negociados no Brasil por nacionais ou estrangeiros ou quando o marketing ou a oferta forem feitos no Brasil, inclusive nos contratos com fornecedores com sede no exterior, ${ }^{183}$ como impõem o Unfair Contract Terms Act de 1977 do Reino Unido, ou a lei alemã (art. 29a da EGBGB), ${ }^{184}$ ou a lei portuguesa de 1985 (art. 33). ${ }^{185}$

Assim, se a conclusão do contrato for precedida por um convite ou indução ao negócio dirigido a ele ou genérico

181 Examinando as leis alemãs de proteção ao consumidor e o novo art. 29a da Lei de Introdução ao Código Civil alemão (EGBGB), conclui no mesmo sentido Reich/Nordausen, p. 95 a 99.

182 Veja meu artigo CIDIP e Reich/Nordhausen, p. 159 e seg.

183 Assim também sugere Lorenzetti, Comercio eletrónico, p. 256 para a Argentina.

184 Winter relembra também que as normas sobre seguros e proteção dos consumidores são imperativas na Alemanha, Winter, p. 1.461.

185 Como ensina Pierre Mayer, p. 521 estas são leis de aplicação imediata que determinam expressamente seu campo de aplicação, impondo sua aplicação a todos os contratos de consumo, se o consumidor tem nestes países a sua residência habitual e realizou todos os atos de conclusão do contrato sem sair do país (Consumidor passivo). Veja como o consumidor passivo no comércio eletrônico é protegido também nos Estados Unidos, nas leis de Ohio, Virginia e Wasington e na lei suíça, in Kronke, Herbert, Applicable Law in Torts and Contracts in Cyberspace, in Internet- Which Court Decides? Which Law Applies, Boele-Woelki, Katharina e Kessedjian, Catherine, Kluwer Law International, 1998, p. 82 e 83. 
por meio da publicidade, ${ }^{186}$ e o consumidor realizou no Brasil todas as medidas necessárias de sua parte para a conclusão do contrato (aceitação válida), a lei brasileira possui contatos mais próximos e deve se aplicar ao contrato internacional de consumo, de forma a favorecer o contratante mais fraco. Deve ser um risco profissional do fornecedor, o qual se utiliza destas tecnologias novas e deste tipo de marketing à distância, o eventual uso das normas imperativas ou de aplicação imediata do país do domicílio ou residência habitual do consumidor, onde a oferta à distância resultou em contratação. ${ }^{187}$ Segundo a doutrina francesa, a proteção dos contratantes mais fracos é melhor realizada se as normas tutelares nacionais são consideradas "leis de aplicação imediata". ${ }^{188}$ A doutrina estrangeira conclui que esta é a prática da maioria dos países do primeiro mundo. ${ }^{189}$ Esta teoria parece ser compartilhada pela jurisprudência do STJ.

O caso de líder em matéria de produtos e serviços estrangeiros e do CDC como standard mínimo de proteção dos consumidores tem origem no STJ. Trata-se de um caso envolvendo um turista brasileiro (consumidor ativo), que retorna ao mercado brasileiro após a compra de uma filmadora com vício. Nesta decisão de líder, o STJ responsabilizou a filial brasileira pela garantia do produto adquirido nos EUA (distribuído pela matriz no Japão e produzido possivelmente na Indonésia ou China), da marca Panasonic, tudo segundo o Código Brasileiro de Direito do Consumidor, considerado "lei de aplicação imediata".

O REsp. 63.981-SP, cujo relator foi

186 A simples publicidade online, com efeitos no país, já pode violar as normas imperativas do direito do consumidor, como comprova a decisão do Tribunal de Frankfurt (OLG Frankfurt), de 31.05.2001, envolvendo publicidade de farmácia holandesa oferecendo medicamento proibido na Alemana. Veja ZIP 2001, p. 1164 a 1168.

187 Assim as conclusões do $5^{\circ}$ Congresso Brasileiro de Direito do Consumidor, in Revista Direito do Consumidor, vol. 33, p. 265: : "11. As normas do CDC, como expressamente consignado em seu artigo $1^{\circ}$, são de "ordem pública e de interesse social", entre a ordem pública local e a ordem pública estrangeira o juiz deve preferir a ordem pública de seu pais; as disposições do CDC, por serem normas de ordem pública, não podem deixar de ser aplicadas às relações de consumo que envolvem consumidores residentes no território nacional, ressalvada a aplicação cumulativa da legislação estrangeira mais favorável. (aprovada por unanimidade)". Veja também FERNANDES, Antônio Joaquim, "Responsabilidade do provedor de Internet", in Revista Direito do Consumidor, vol. 26, p.49.

188 Assim conclui o grande professor de DIPr. francês, Pierre MAYER, p. 531.

189 Veja, por todos, KRONKE, p. 82, e JUNKER, RIW 1999, p. 815. Assim conclui até mesmo o advogado da Microsoft,. em seu Curso de Haia de 2001, SMITH, p. 330 mesmo protestando contra esta prática e pedindo que a internet seja regulada de forma mínima. 
o min. Sálvio de Figueiredo Teixeira, foi decidido em 4 de maio de 2000, com a seguinte ementa:

DIREITO DOCONSUMIDOR. FILMADORA. DEFEITO DA MERCADORIA. RESPONSABILIDADE DA EMPRESA NACIONAL DA MESMA MARCA (PANASONIC). ECONOMIA GLOBALIZADA. PROPAGANDA. PROTEÇÃO AOCONSUMIDOR. PECULIARIDADE DA ESPÉCIE. SITUAÇÕES A PONDERAR NOS CASOS CONCRETOS. NULIDADEDOACÓRDÃO ESTADUAL REJEITADA, PORQUE SUFICIENTEMENTE FUNDAMENTADO. RECURSO CONHECIDO E PROVIDO NO MÉRITO, POR MAIORIA. I - Se a economia globalizada não mais tem fronteiras rigidas e estimula e favorece a livre concorrência, imprescindivel que as leis de proteção ao consumidor ganhem maior expressão em sua exegese, na busca do equilibrio que deve reger as relações jurídicas, dimensionando-se, inclusive, o fator risco, inerente à competitividade do comércio e dos negócios mercantis, sobretudo, quando em escala internacional, em que presentes empresas poderosas, multinacionais, com filiais em vários paises, sem falar nas vendas hoje efetuadas pelo processo tecnológico da informática e no forte mercado consumidor que representa o nosso país. II - O mercado consumidor, não há como negar, vê-se hoje 'bombardeado' diuturnamente por intensa e hábil propaganda, a induzir a aquisição de produtos, notadamente os sofisticados de procedência estrangeira, levando em linha de conta diversos fatores, dentre os quais, e com relevo, a respeitabilidade da marca. III - Se empresas nacionais se beneficiam de marcas mundialmente conhecidas, incumbe-lhes responder também pelas deficiências dos produtos que anunciam $e$ comercializam, não sendo razoável destinar-se ao consumidor as conseqüencias negativas dos negócios envolvendo objetos defeituosos. ${ }^{190}$

Como se observa, se em caso envolvendo turista brasileiro, cuja única conexão com o Brasil era o domicílio do consumidor, o CDC foi aplicado, parece-me provável que o STJ deverá considerar o CDC também "lei de aplicação imediata" em Direito Internacional Privado nos demais casos, em especial quando o consumidor passivo contratar no comércio à distância, aplicando o $\mathrm{CDC}$, antes do art. $9^{\circ}$ da LICC/42.

A solução do STJ foi a mesma da União Européia, que considera as Diretivas de proteção do consumidor como "imperativas", ${ }^{191}$ aplicando-as

190 DJ 20.11.2000, na íntegra, em sua primeira versão, in RDC 35, p. 270 e seg.

191 Assim, como conclusão geral, Bröcker, Marion, Verbraucherschutz im Europäischen Kollisionsrecht. Peter Lang, Frankfurt am Main, 1998, p. 138 e Junker, IPRAX 1998, p. 74. Também Jayme, IPRAX 1999, p. 412. Assim as Diretivas impõem, por exemplo, a Diretiva 1999/44/CE sobre garantias: "art. $7^{\circ}$ (2) Os Estados membros tomarão as medidas necessárias para que o consumidor não perca a proteção assegurada por esta Diretiva, quando o direito de um Estado terceiro é escolhido para regular o contrato, desde que o contrato possua um vínculo estreito com o território de um Estado Parte (da E. U.) " in RDC 38/313. 
sempre como standards mínimos de proteção dos consumidores europeus, sempre que a lei aplicável é de país fora da zona. A conclusão é de que os interesses de proteção do agente mais vulnerável superam os de harmonia das decisões, melhor seria regular o tema em norma especial na Lei de Introdução ao Código Civil, a exemplo dos artigos 29 e 29 a da lei alemã ${ }^{192}$ e do direito francês.

A Lei de Introdução ao BGB alemã (EGBGB) já conhecia uma norma especial para consumidores, o criticado art. 29 EGBGB, inspirado no art. $5^{\circ} \mathrm{da}$ Convenção de Roma de 1980, mas que já era considerado complicado e pouco "sólido" pela doutrina alemã. ${ }^{193}$ O novo art. 29a da EGBGB é ainda mais complexo e mais difícil, como se verifica, no que passo a traduzir livremente:

Art. 29a EGBGB. (1) Se a lei escolhida para regular um contrato não é de um Estado-membro da UE ou do Espaço Econômico Europeu, são também aplicáveis as normas das leis que incorporaram Diretivas de proteção dos consumidores (leis de proteção do consumidor sobre Condições Gerais Contratuais, a Lei de Contratos à Distância e de Time-sharing), quando o contrato tenha um vínculo estreito com um ou mais países da União Européia (EU) ou do Espaço Econômico Europeu (EEE); (2) Um vinculo estreito existe quando: (1) O contrato seja feito em virtude de uma oferta pública, publicidade ou atos negociais semelhantes realizados em um dos Estados da UE ou EEE. (2). A outraparte contratante, quando declarou a sua vontade ou aceitou a oferta, tenha domicilio nos paises da UE ou EEE. (3) A lei sobre time-sharing é aplicável ao contrato, regido por uma lei de um país não membro da UE ou EEE, quando o imóvel localize-se em um Estado da UE ou EEE. (4) Diretivas de proteção do consumidor no sentido deste artigo são: 1. Diretiva 93/13/CEE, sobre cláusulas abusivas; 2. Diretiva 94/47/ CEE, sobre time-sharing 3. Diretiva 97/ $7 / C E$, sobre contratos à distância. ${ }^{194}$

Em resumo, caso a norma indicada aplicável pelo DIPr. alemão for a de um país em que as diretivas de proteção do consumidor (normas materiais) não se aplicam, elas serão consideradas de ordem pública internacional e de aplicação imperativa (mandatory) ou obrigatória, cumulando-se como um patamar mínimo de proteção à lei aplicável ao contrato, tudo para a proteção do consumidor europeu. Também a França introduziu no Código de consumo uma regra de DIPr. (art. L. 121-20-6 do

192 Winter relembra que também as normas sobre seguros e proteção dos consumidores são imperativas na Alemanha, Winter, p. 1461.

193 Assim se manifestou Junker, citando Christian von Bar, in IPRAX 1998, p. 68.

194 Texto original em alemão, livremente traduzido, publicado in IPRAX 1999, p. [304] VII e in BGBL. Teil $1 \mathrm{n}^{\circ}$ 8/29, Juni 2000, p. 901. 
Code de la Consommation), ${ }^{195}$ alcançando o mesmo resultado de aplicação imperativa das diretivas de proteção dos consumidores.

Parte da doutrina brasileira, em especial a voltada para o comércio eletrônico, considera esta aplicação direta do Código de Defesa do Consumidor demasiadamente extensiva e defende a aplicação das regras tradicionais nacionais de conflitos de lei. ${ }^{196}$ Apoiando a solução da LICC de 1942 e a aplicação da lei do fornecedor (ou porque propõe o contrato - art. $9^{\circ}, \S 2^{\circ}$ LICC -, ou porque escolhe a sua lei no contrato autonomia da vontade em DIPr., ou porque tem a conexão mais estreita ao realizar a prestação característica - lei do lugar da execução), consideram estes autores que é risco do consumidor fazer uma transação à distância internacional e a aplicação da lei mais favorável ao fornecedor é uma consequiência aceitável. ${ }^{197}$

Já a doutrina consumerista geralmente desconhece a teoria das leis de aplicação imediata em DIPr. e defende - de lege ferenda - a aplicação da lei local do domicílio ou a residência do consumidor, se a oferta for feita no Brasil $^{198}$ ou que as normas do CDC são de ordem pública internacional. ${ }^{199}$ Dada máxima vênia a este esforço louvável de proteção dos contratantes mais fracos, o uso excessivo da ordre public international, ${ }^{200}$ se bem que comum

195 A regra do Code de la Consommation é o art. L. 121-20-6, com a seguinte redação: "Lorsque les parties ont choisi la loi d'un État non membre de la Communauté européenne pour régir le contrat, le juge devant lequel est invoquée cette loi est tenu d'en écarter l'application au profit des dispositions plus protectrices de la loi de la résidence habituelle du consommateur assurant la transposition de la directive 97/7/CE du Parlement européen et du Conseil du 20 mai 1997 concernant la protection des consommateurs en matière de contrats à distance, lorsque cette résidence est situé dans un Etat membre."

196 Cf. Greco, 2000, p. 50.

197 Veja. Greco, 2000, p. 50 e Benevides de Carvalho, p. 108.

198 Assim Lucon, Paulo Henrique dos Santos. "Competência no comércio e no ato ilícito eletrônico, in DeLucca e Simão, Direito e Internet- Aspectos Jurídicos Relevantes, São Paulo, Edipro, 2000, p. 351 a 370, p. 354-355.

199 Assim Martins Castro, Luiz Fernando. O comércio eletrônico e a Defesa do Consumidor no Direito Brasileiro e no Mercosul, in Internet e Direito- Reflexões doutrinárias, Roberto Rodrigues da Silva Júnior (Coord.), Ed. Lumen Juris, Rio de Janeiro, 2001, p. 138 e 139, veja também conclusão independente do Congresso de Minas 2000, in RDC 35, p.265.

200 Esta é uma teoria francesa do início do século XX: "les lois d'intérêt général qui s'imposent toujours à son observation sur le territoire où elles ont été édictées. Nous comprendrons ces dernières sous le nom de lois d'ordre public international." Assim André Weiss apud Anderegg, Kirsten, Ausländische Eingriffsnormen im internationalen Vertragsrecht, Ed. Mohr, Tübingen, 1989, p. 9. Sobre Código de Bustamante, veja Samtleben, Jürgen. Derecho Internacional Privado en América Latina- Teoría y Práctica del Código Bustamante, Ed. Depalma, vol. I, Buenos Aires, 1963, p. 270. 
nos países latino-americanos (veja-se o Código de Bustamante), traz sérias perturbações ao sistema de DIPr. ${ }^{201} \mathrm{O}$ resultado seria de que qualquer lei estrangeira indicada aplicável em qualquer questão de consumo passaria a ofender a nossa ordem pública internacional (art. 17 LICC), simples-mente por não ser igual à lei brasileira, descaracterizando a ordem pública em DIPr. como uma exceção ao sistema, em que se aplica a lex fori (no caso, a lei brasileira) face ao resultado concreto da aplicação da lei estrangeira, o qual, este sim, ofenderia os pilares e valores básicos de nosso ordenamento jurídico. Esta solução radical e genérica só pode ser aceita se considerarmos que as regras materiais do CDC seriam (algumas) de ordem pública interna-cional por se caracterizarem ou positivarem direitos fundamentais (art. $4^{\circ}$ do Código de Bustamante). Sendo assim, parece-me que o melhor é atualizar as nossas regras de DIPr. em uma nova LICC.

Neste sentido, proponho como norma especial de proteção do consumidor a seguinte redação para um artigo 9bis a ser incluído na LICC/42 ou para compor um eventual novo projeto de lei:

Art. $9^{\circ}$ bis. Os contratos e as transações envolvendo consumidores, especialmente os contratados à distância, por meios eletrônicos, de telecomunicações ou por telefone, estando o consumidor em seu país de domicílio, serão regidos pela lei deste pais ou pela lei mais favorável ao consumidor, escolhida entre as partes, se for a lei do lugar da celebração do contrato, lei do lugar da execução do contrato, da prestação característica ou lei do domicílio ou sede do fornecedor de produtos e serviços.

$\S 1^{\circ}$. Aos contratos celebrados pelo consumidor, estando ele fora de seu pais de domicilio, será aplicada a lei escolhida pelas partes, dentre a lei do lugar de celebração do contrato, a lei do lugar da execução ou a lei do domicilio do consumidor.

$\S 2^{\circ}$. Em todos os casos, aplicar-se-ão necessariamente as normas do pais do foro que tenham caráter imperativo, na proteção do consumidor.

$\S 3^{\circ}$. Tendo sido a contratação precedida de qualquer atividade negocial, de marketing, do fornecedor ou de seus representantes, em especial envio de publicidade, correspondência, e-mails, prêmios, convite, manutenção de filial ou representantes de demais atividades voltadas para o fornecimento de produtos e serviços, a atração de clientela no país de domicilio do consumidor, aplicar-se-á necessariamente as normas imperativas deste pais, na proteção do consumidor, cumulativamente às normas imperativas do foro e à lei aplicável ao contrato ou à relação de consumo.

\section{Os acidentes envolvendo pro-} dutos e serviços defeituosos e a necessidade de uma norma especial sobre lei aplicável aos acidentes de consumo, um foro privilegiado da vítima e uma norma especial de ordem pública

Segundo os autores argentinos, há

201 Assim também conclui, Pierre Mayer, p. 531. 
um DIPr. do Mercosul. ${ }^{202}$ Já, autores uruguaios $^{203}$ e brasileiros preferem destacar as normas como sendo de Processo Civil Internacional. ${ }^{204}$ Certo é que o Protocolo de San Luis, de 1996, regula o foro e a lei aplicável à responsabilidade civil por acidentes de trânsito, logo, traz normas de DIPr., enquanto os demais tratados tratam efetivamente de processo e de normas auxiliares ao DIPr. ${ }^{205}$

No âmbito do Mercosul, pois, temos o Protocolo sobre Matéria de Responsabilidade Civil Emergente de Acidentes de Trânsito entre os EstadosPartes do Mercosul, assinado em San Luis, em 25 de agosto de 1996, o qual estabelece "o direito aplicável e a jurisdição internacionalmente competente em casos de responsabilidade civil emergente de acidentes de trânsito ocorridos no território de um EstadoParte, nos quais participem, ou dos quais resultem atingidas, pessoas domiciliadas em outro Estado-Parte" (art. $1^{\circ}$ ). Este protocolo foi saudado pela doutrina como necessário, ${ }^{206}$ e suas normas, mais flexíveis que as atuais normas nacionais, como adequadas. ${ }^{207}$ As normas do referido protocolo estabelecem a aplicação da lex loci delicti commissi e determinam exceções para as regras com vínculos mais estritos, respeitadas as regras imperativas do lugar do acidente. $\mathrm{O}$ Protocolo não regula casos de conumo, mas pode servir de modelo à nossa sugestão e assim dispõe:

Art. $3^{\circ}$. La responsabilidad civil por accidentes de tránsito se regulará por el derecho interno del Estado Parte en cuyo territorio se produjo el accidente.

Si en el accidente participen o resulten afectadas únicamente personas domiciliadas en otro Estado Parte, el mismo se regulará por el derecho interno de éste último.

Art. $5^{\circ}$. Cualquiera fuere el derecho aplicable a la responsabilidad, serán tenidas en cuenta las regras de circulación y seguridad en vigor en el lugar y en el momento del accidente. ${ }^{208}$

No âmbito do Mercosul, em 1996, também foi assinado um protocolo específico sobre jurisdição para o

202 Assim Klor, p. 229 e seg.; e Fernandez Arroyo, p. 42.

203 Assim Hargain/Mihali, p. 537 e seg.

204 Assim Pabst, IPRAX, 1999, p. 76, que cita opiniões de Araújo, Almeida, Martins, Borba Casella e Pabst, p. 31. Veja meu artigo na Revista do UNIDROIT.

205 Esta também é a opinião de Samtleben, em seu artigo publicado in RabelsZ, 63 (1999), p. 1 e seg.

206 Assim Fernandez Arroyo, p. 43.

207 Veja meu artigo sobre o tema, em que há sugestão de normas para o Brasil, que foram levadas para a Reunião de Ministros, Revista dos Tribunais, vol. 629 (mar/1988), p. 89-92. 208 Texto reproduzido de Araújo/Marques/Reis, p. 155-156. 
consumidor que ficou conhecido como "Protocolo de Santa Maria", cidade brasileira onde foi negociado, que traz um foro especial privilegiado para o consumidor e que poderia ser utilizado em caso de acidentes de consumo. No CDC há atualmente um foro privilegiado para o consumidor, em seu art. 101, inciso I da Lei 8.078/90. Dúvida há se o STF abandonará sua preferência pelos art. 88 e 89 do CPC em prol do foro privilegiado do consumidor do art. 101, I do CDc, daí a importância de uma norma epecial sobre o tema, em convenção ou na reforma do CPC.

Efetivamente são estas as tendências internacionais em matéria de acidentes de consumo: assegurar um foro privilegiado aos consumidores, aplicar a teoria da ubiqüidade em matéria de acidentes de consumo (indicando ou a lei do lugar do ato ou tentativa de delito, lex loci delicti commissi, ou lei do lugar onde os efeitos do delito ou acidente fizeram-se sentir), indicar a lei do domicílio ou residência do consumidor ( $§ 40,2$ EGBGB) ou a sua cumulação com a lei do mercado em que o bem foi vendido ou mesmo cláusulas escapatórias e normas de favor consumidor. ${ }^{209}$

Especialmente em matéria de riscos novos da tecnologia ou biotecnologia, como os OGMs ou trangênicos, mister relembrar a existência da Convenção de Haia de outubro de 1973 sobre responsabilidade pelo fato do produto. ${ }^{210}$ A convenção é flexível o suficiente e representaria um avanço considerável se pudesse o Brasil a ela aderir ou ratificá-la, conforme o caso. ${ }^{211}$ A convenção traz a responsabilidade de toda a cadeia de fornecedores, inclusive distribuidores e importadores $\left(\operatorname{art.} 3^{\circ}\right.$ ), conhece a noção de vício da informação ou falha na informação sobre os riscos e ingredientes dos produtos (art. $1^{\circ}$ ) e inclui os produtos agrícolas e naturais $\left(\operatorname{art.} 2^{\circ}\right) .^{212}$ A Convenção de Haia de 1973 indica como aplicável (art. $4^{\circ}, 5^{\circ}$ e $6^{\circ}$ ) a lei do país onde ocorreu ou deveria ocorrer o dano (lex loci delicti) ou a lei do país de residência habitual das pessoas vítimas. ${ }^{213}$ A tendência mundial é de ter regras especiais sobre os delitos de

209 Veja Kadner Graziano, Thomas. Europäisches Internationales Deliktsrecht, Mohr, Tübingen, 2003, p. 67 e seg.

210 Wandt, p. 58 ss.

211 Veja Lima Marques, Claudia. Novos rumos do Direito internacional privado quanto às obrigações resultantes de atos ilícitos, in Revista dos Tribunais (São Paulo), vol. 629 (mar. 1988), p. 72-92.

212 Veja Conférence de La Haye de droit internationale privé, Actes et documents de la douzième session - 2 au 21 octobre 1972, Tome III - Responsabilité du fait des produits, Ed. Bureau Permanent de la Conférence, La Haye, 1974, p. 246-250.

213 Veja Freitag, Robert, Der Einfluss des Europäischen Gemeinschaftsrechts auf das internationale Produkthaftungsrecht, Mohr, Tübingen, 2000, p. 171ss. 
consumo, que podem ser catastróficos ou não, individuais ou coletivos, utilizando a lei do lugar de aquisição ou lei do mercado de origem (lex originis), ou a lei mais favorável ao consumidor, o que pode ser muito importante no futuro, com os novos danos ainda não identificados. ${ }^{214}$

Acidentes e delitos de consumo são temas muito ligados à exceção de ordem pública e aos direitos fundamentais dos cidadãos. Qualidade e segurança, de produtos e serviços oferecidos no mercado, é hoje um dos anseios de dignidade da pessoa humana. Sendo assim, cabe lembrar a importância que a LICC, tenha clara uma norma sobre a chamada ordem pública positiva, ou os efeitos protetivos dos direitos fundamentais também em DIPr. Assim também a tradicional exceção de ordem pública tem um claro fim social e de proteção, não só do sistema do DIPr, mas também, nos países da família de direito continental-europeu, das políticas públicas ou objetivos de harmonia social interna. ${ }^{215}$ Minha sugestão seria incluir um parágrafo único no atual art. 17 da LICC, que fortemente influenciado pelo art. $6^{\circ} \mathrm{da}$ EGBGB e retirando as menções desnecessárias à soberania nacional e aos bons costumes, assim ficaria redigido:

Art. 17. As leis, atos e sentenças de outro pais, bem como quaisquer declarações de vontade, não terão eficácia no Brasil quando ofenderem a ordem pública.

$\S$ único. A norma estrangeira indicada não terá eficácia quando o resultado da aplicação desta for incompativel com os princípios fundamentais do direito brasileiro especialmente com os direitos fundamentais.

E, por fim, para regular a contento os acidentes de consumo, ${ }^{216}$ mister sugerir uma regra especial para estes delitos ou atos ilícitos envolvendo consumidores, sem prejuízo do disposto nos art. 12, 13 e 14 do CDC. A redação poderia ser esta:

Art. $9^{\circ}$ Para reger as obrigações resultantes de atos ilicitos, acidentes de consumo ou da responsabilidade pelo fato do produto ou serviço de consumo será aplicável, em princípio, a lei do lugar onde o ato ocorreu ou aconteceu a tentativa ou, em caso de omissão, devia ter ocorrido o fato. Excepcionalmente, será aplicável a lei do lugar onde os efeitos se fizeram sentir, caso este lugar coincida com o lugar do foro.

$\S 1^{\circ}$ Caso nenhuma das partes possua seu domicilio ou sede no país onde o acidente ocorreu ou seus efeitos se fizeram sentir, poderão as partes, no processo, escolher o Direito a ser aplicado entre o direito do foro, do domicilio ou residencia habitual comum, do lugar do registro dos veículos ou lugar do ato ou do

214 Kadner Graziano, p. 78.

215 Bucher, p. 60 e eg.

216 Veja meu artigo in RT 629, p. 89 e seg. 
mercado de comercialização do produto ou serviço.

$\S 2^{\circ}$ Caso as partes não exerçam o direito de escolha previsto no parágrafo primeiro e, possuindo as partes seu domicílio ou residência habitual no mesmo país, será a lei deste país a aplicável.

$\S 3^{\circ}$ As leis indicadas aplicáveis não excluem a aplicação das normas imperativas previstas pela lei do lugar do ato ilícito.

\section{CONCLUSÃO}

Concluímos, pois, este estudo em homenagem ao prof. dr. José Francisco Rezek, da UnB, convencidos da necessidade e da oportunidade da academia brasileira sugerir hoje novas normas especiais de Direito Internacional Privado para a proteção contratual e extracontratual dos consumidores, a serem incorporadas na LICC, justamente agora que - com a aprovação do novo Código Civil - estuda-se a sua modificação (projeto de Lei 243/2002).

A minha singela sugestão seria a seguinte:

Art. $9^{\circ} \mathrm{bis}$. Os contratos e as transações envolvendo consumidores, especialmente os contratados à distância, por meios eletrônicos, de telecomunicações ou por telefone, estando o consumidor em seu pais de domicílio, serão regidos pela lei deste país ou pela lei mais favorável ao consumidor, escolhida entre as partes, se for a lei do lugar da celebração do contrato, lei do lugar da execução do contrato, da prestação característica ou lei do domicilio ou sede do fornecedor de produtos e serviços.

$\S 1^{\circ}$ Aos contratos celebrados pelo consumidor, estando ele fora de seu país de domicilio, será aplicada a lei escolhida pelas partes, dentre a lei do lugar de celebração do contrato, a lei do lugar da execução ou a lei do domicílio do consumidor.

$\S 2^{\circ}$ Em todos os casos, aplicar-se-ão necessariamente as normas do país do foro que tenham caráter imperativo, na proteção do consumidor.

$\S 3^{\circ}$ Tendo sido a contratação precedida de qualquer atividade negocial, de marketing, do fornecedor ou de seus representantes, em especial envio de publicidade, correspondência, e-mails, prêmios, convite, manutenção de filial ou representantes de demais atividades voltadas para o fornecimento de produtos e serviços, a atração de clientela no país de domicílio do consumidor, aplicar-se-ão necessariamente as normas imperativas deste país, na proteção do consumidor, cumulativamente às normas imperativas do foro e à lei aplicável ao contrato ou à relação de consumo.

Art. $9^{\circ}$ ter. Para reger as obrigações resultantes de atos ilicitos, acidentes de consumo ou da responsabilidade pelo fato do produto ou serviço de consumo será aplicável, em princípio, a lei do lugar onde o ato ocorreu ou aconteceu a tentativa ou, em caso de omissão, devia ter ocorrido o fato. Excepcionalmente, será aplicável a lei do lugar onde os lefeitos se fizeram sentir, caso este lugar coincida com o lugar do foro.

$\S 1^{\circ}$ Caso nenhuma das partes possua seu domicílio ou sede no país onde o acidente ocorreu ou seus efeitos se fizeram sentir, poderão as partes, no processo, escolher o Direito a ser 
aplicado entre o direito do foro, do domicílio ou residencia habitual comum, do lugar do registro dos veículos ou lugar do ato ou do mercado de comercialização do produto ou serviço.

$\S 2{ }^{\circ}$ Caso as partes não exerçam o direito de escolha previsto no parágrafo primeiro e, possuindo as partes seu domicílio ou residência habitual no mesmo país, será a lei deste país a aplicável.

$\S 3^{\circ}$ As leis indicadas aplicáveis não excluem a aplicação das normas imperativas previstas pela lei do lugar do ato ilícito.

Art. 17 - As leis, atos e sentenças de outro país, bem como quaisquer declarações de vontade, não terão eficácia no Brasil quando ofenderem a ordem pública.

$\S$ único. A norma estrangeira indicada não terá eficácia quando o resultado da aplicação desta for incompativel com os principios fundamentais do direito brasileiro especialmente com os direitos fundamentais.

Como se observa, a sugestão não inclui os aspectos de processo civil internacional para não duplicar os esforços atualmente realizados no UNIDROIT $^{217}$ e na Convenção de Haia, ${ }^{218}$ mas norma semelhante às previstas no Protocolo de Santa Maria poderiam ser incluídas ou na nova LICC ou no CPC brasileiro.

Igualmente, se assim tiver por bem o legislador, pode ser incluída uma cláusula escapatória, semelhante a que sugeri para a nova CIDIP sobre proteção do consumidor:

Art. ....A lei indicada como aplicável pode excepcionalmente não ser utilizada pelo juiz, se, tendo em vista todas as circunstâncias do caso, a conexão com a lei indicada aplicável mostrar-se superficial e o caso encontrar-se muito mais vinculado estreitamente a outra lei, mais favorável ao consumidor.

Neste sentido, pedindo desculpas ao mestre pela singeleza das sugestões aqui realizadas, que espero sejam construtivas, reafirmo minha viva admiração intelectual pela sua sólida obra, a qual foi decisiva para a evolução do Direito Internacional brasileiro. Maio de 2004.

217 Veja sobre o texto já existente, Projet de Principes relatifs à la procédure transnationale, in Uniform Law Review/ Revue de droit uniforme (UNIDROIT), 1119 e seg. ou no site www.unidroit.org, comentário de Ferrand, Frédérique "Les 'principes' relatifs à la procédure civile transnationale sont-ils autosuffisants? De la nécessité ou non de les assortir de 'règles' dans le projet ALI/Unidroit', in Uniform Law Review/ Revue de droit uniforme (UNIDROIT), 2001, p. 995 e seg. e meu artigo, Procédure civile internationale et Mercosur : pour un dialogue des règles universelles et régionales, p. 465 e seg..

218 Veja site www.hcch.net. 
